\title{
Exploration of regional and global cost-supply curves of biomass energy from short-rotation crops at abandoned cropland and rest land under four IPCC SRES land-use scenarios
}

\author{
Monique Hoogwijk ${ }^{a, b, *, 1}$, André Faaij ${ }^{a}$, Bert de Vries ${ }^{b}$, Wim Turkenburg ${ }^{a}$ \\ ${ }^{a}$ Department of Science, Technology and Society, Copernicus Institute, Utrecht University, Heidelberglaan 2, 3584 CS Utrecht, The Netherlands \\ ${ }^{b}$ National Institute of Public Health and the Environment (RIVM), Netherlands Environmental Assessment Agency, Bilthoven, \\ The Netherlands
}

\section{A R T I C L E I N F O}

Article history:

Received 6 March 2006

Received in revised form

18 February 2008

Accepted 5 April 2008

Available online 18 June 2008

\begin{abstract}
A B S T R A C T
We explored the production cost of energy crops at abandoned agricultural land and at rest land at a regional and a global level to the year 2050 using four different land-use scenarios. The estimations were based on grid cell data on the productivity of short-rotation crops on the available land over time and assumptions regarding the capital and the labour input required to reach these productivity levels. It was concluded that large amounts of grown biomass at abandoned agricultural land and rest land, 130-270 $\mathrm{EJ} \mathrm{yr}^{-1}$ (about $40-70 \%$ of the present energy consumption) may be produced at costs below $\$ 2 \mathrm{GJ}^{-1}$ by 2050 (present lower limit of cost of coal). Interesting regions because of their low production cost and significant potentials are the Former USSR, Oceania, Eastern and Western Africa and East Asia. Such low costs presume significant land productivity improvements over time and cost reductions due to learning and capital-labour substitution. An assessment of biomass fuel cost, using the primary biomass energy costs, showed that the future costs of biomass liquid fuels may be in the same order of the present diesel production costs, although this may change in the long term. Biomass-derived electricity costs are at present slightly higher than electricity baseload costs and may directly compete with estimated future production costs of fossil fuel electricity with $\mathrm{CO}_{2}$ sequestration. The present world electricity consumption of around $20 \mathrm{PWhyr}^{-1}$ may be generated in 2050 at costs below $\$ 45 \mathrm{MWh}^{-1}$ in $\mathrm{A} 1$ and $\mathrm{B} 1$ and below $\$ 55 \mathrm{MWh}^{-1}$ in $\mathrm{A} 2$ and $\mathrm{B} 2$. At costs of $\$ 60 \mathrm{MWh}^{-1}$, about 18 (A2) to 53 (A1) $\mathrm{PWhyr}^{-1}$ can be produced.
\end{abstract}

(c) 2008 Elsevier Ltd. All rights reserved.

\footnotetext{
*Corresponding author at: Department of Science, Technology and Society, Copernicus Institute, Utrecht University, Heidelberglaan 2, 3584 CS Utrecht, The Netherlands Tel.: +3130 2537600; fax: +31302537601.

E-mail address: M.Hoogwijk@ecofys.nl (M. Hoogwijk).

Abbreviations: SRES scenarios, emission scenarios developed in the context of the IPCC and named after the title of the report Special Report on Emission Scenarios; BIGCC, Biomass integrated gasification combined cycle; FT-diesel, Fischer Tropsch-diesel; CCS, Carbon Capture and Storage; GDP, Gross Domestic Product; GWP, Gross World Product.

${ }^{1}$ Currently at Ecofys Netherlands BV, Kanaalweg 16G, P.O. Box 8408, 3503 RK Utrecht, The Netherlands. 0961-9534/\$- see front matter ๔ 2008 Elsevier Ltd. All rights reserved.
}

doi:10.1016/j.biombioe.2008.04.005 


\section{Introduction}

In recent years, the interest in biomass energy has increased considerably worldwide. There are several reasons for this: biomass is widely available and it has the potential to produce modern energy carriers such as electricity and liquid transport fuels that are clean, convenient and easily used in the present energy supply system. Biomass energy can also be produced in a carbon-neutral way and can contribute to (local) socio-economic development. The present contribution of modern biomass to the primary energy consumption is

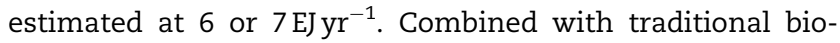
mass, its share in the total primary energy supply is 9-13\% [1]. Various scenario studies suggest potential market shares of modern biomass till the year 2050 of about 10-50\% [2]. However, such high shares can only be achieved if biomass becomes available at competitive costs. At present, biomass energy competes in some places with conventional sources with the use of policy intervention, like a carbon tax. Examples are the production of ethanol in Brazil and the USA [3,4], district heating using biomass in Scandinavian countries and the generation of electricity by (co-)combustion of biomass in power plants in various countries $[1,5,6,8]$.

At present, biomass residues from the forestry or agricultural sector are mostly used to produce modern biomass energy carriers at low costs. However, biomass originating from energy crops has a much larger potential than biomass from residue flows [2,9]. But specially cultivated biomass for energy purposes currently results in high fuel and electricity costs in most cases, particularly where land and labour costs are high. Therefore, insight in potential cost and supply developments of energy crops and biomass energy carriers is important. Cost-supply curves of biomass energy have been studied at a regional [10] or national level [11,12] but no research has been conducted at global scale. This would be interesting for both energy modellers and engineering approaches for policy assessments.

In this paper we explore the long-term regional and global cost-supply curves of short-rotation energy crops and liquid fuel and electricity produced from such biomass. These curves give insight in the long-term economic and market potential of biomass energy. This endeavour is complicated by various reasons, see e.g. [13]. There is limited experience with energy crop production. Moreover, the availability and cost of land for energy crop production as well as soil productivity and required labour and capital inputs are sitespecific. For the assessment of regional cost-supply curves, data from detailed, geographical analysis are needed. These data are not available for all possible sites and have to be derived from more generic assumptions, which we do here. Furthermore, the development of various important parameters such as land use changes have been included using different scenarios. Land-use may change due to changes in land quality and land demand because of changes in population, economy and diet.

This paper is a sequel to an earlier assessment of the geographical and technical potential of energy crops [9]. There, we used land-use scenarios to estimate the geographical and technical potential of energy crops for 17 world regions. The geographical potential has been defined as the product of the available area for energy crops and the corresponding productivity level for energy crops. The available areas differ for each of the scenarios. The technical potential is defined as the geographical potential reduced by the losses due to the conversion efficiencies. This paper estimates the production costs associated with the energy crops and the derived fuel or electricity for the same scenarios and geographical regions. By cumulating the geographical and technical potential as a function of the production costs, we construct the cost-supply curve of energy crops and of fuels and electricity derived from these crops.

Our approach simplifies various economic and ecological aspects of primary biomass energy production. We have not differentiated between different production systems, e.g. a high input system with irrigation and fertilisation and a more extensive system without irrigation or fertilisation. Neither has an extensive production system been investigated nor have we conducted an ecological assessment of the energy crops. We also do not include the possible cost increase as a result of possible negative ecological impacts, e.g. salinity of the soil or an increase in $\mathrm{N}_{2} \mathrm{O}$ emissions or decrease due to potential ecological benefits such as erosion prevention or improvements of the C-content in the soil, see e.g. $[6,7]$.

We start with a description of the methodology used in this study to investigate biomass energy cost-supply curves (Section 2). Next, we focus on the quantification of the input parameters with an emphasis on cost parameters (Section 3). Section 4 deals with the results of the cost-supply curve of primary biomass, whereas the cost-supply curve including the conversion to secondary energy carriers in the form of electricity and fuels is presented in Section 5. A sensitivity analysis of the results and a discussion is given in Section 6 and Section 7. Section 8 presents a summary and the conclusions of this study.

\section{Methodology}

\subsection{Aggregation level, crop choice and land-use scenarios}

This study is a sequel of an earlier study [9] using the IMAGE 2.2 model for the assessment of the technical and geographical potential of energy crops. For assumptions and motivation related to these potential figures we refer to this paper. Most important assumptions on regional aggregation level, crop choice and land-use scenarios are summarised in Table 1.

Fig. 1 shows the variation of land-use cover over time and the available land areas as included in this study based on [9].

\subsection{The cost-supply curve of primary biomass energy from energy crops}

The production costs of energy crops are assessed based on regional and global average data and assumptions about future developments. We aggregate the cost inputs in three parts: the labour costs, the capital costs and the land rental 
Table 1 - Summary of most important characteristics of this study

\begin{tabular}{|c|c|}
\hline Geographical scale & Grid cell level $0.5^{\circ} \times 0.5^{\circ}$ \\
\hline Regions & $\begin{array}{c}17 \text { world regions: Canada, USA, } \\
\text { Central America, South } \\
\text { America, Northern Africa, } \\
\text { Western Africa, Eastern Africa, } \\
\text { Southern Africa, OECD Europe, } \\
\text { Eastern Europe, Former USSR, } \\
\text { Middle East, South Asia, East } \\
\text { Asia, South East Asia, Oceania, } \\
\text { Japan }\end{array}$ \\
\hline Type of energy crops & $\begin{array}{l}\text { Short-rotation crops in } \\
\text { commercial large-scale } \\
\text { plantations. Which species is } \\
\text { preferred depends on climate } \\
\text { conditions and soil quality }\end{array}$ \\
\hline Land use type available & $\begin{array}{l}\text { Abandoned agricultural land } \\
\text { and 'rest' land }\end{array}$ \\
\hline Rest land & $\begin{array}{l}\text { Rest land includes all the } \\
\text { remaining non-productive land } \\
\text { that can be used for energy crop } \\
\text { production. The rest land } \\
\text { category excludes bioreserves, } \\
\text { forest, agricultural and urban } \\
\text { areas and is calculated after } \\
\text { satisfying the demand for food, } \\
\text { fodder and forestry products }\end{array}$ \\
\hline Abandoned agricultural land & $\begin{array}{l}\text { The agricultural land not } \\
\text { required after satisfying the } \\
\text { demand for food, fodder and } \\
\text { forestry products. As such it is } \\
\text { the land taken out of } \\
\text { agricultural production due to } \\
\text { less demand, higher land } \\
\text { productivities elsewhere or both }\end{array}$ \\
\hline $\begin{array}{l}\text { Land use scenarios for food } \\
\text { and fodder demand and } \\
\text { supply }\end{array}$ & $\begin{array}{l}\text { IPCC SRES scenarios simulated } \\
\text { with the IMAGE } 2.2 \text { model } \\
\text { [14-18] }\end{array}$ \\
\hline
\end{tabular}

costs. These represent all costs that are made during the production chain, which consists of establishment of the plantation (plowing and weed control), planting of cuttings, management of the plantation, e.g. by application of fertilisers, harvest of the crop and the break-up of the plantation, e.g. $[6,19]$. In addition, costs of transport of the raw feedstock are included.

In the literature estimates have been made of the production costs of woody biomass from energy crops at project level. A broad range of costs is found, ranging from 2.5 to $16.4 \$_{2000} G^{-1}$ in Europe, 2.1 to $7.4 \$_{2000} G^{-1}$ in the USA, 1.0 to $5.0 \$_{2000} \mathrm{GJ}^{-1}$ in Latin America and 0.5 to $1.3 \$_{2000} \mathrm{GJ}^{-1}$ in Asia $[6,12,19-31]$. This large range can partly be explained by the wide variety of energy crops, locations and time horizons in these studies. Our purpose is to construct a generic cost estimate procedure that can be applied to conduct long-term regional and global cost-supply curves. This is done by following a more theoretical and generic approach.

To determine regional cost-supply curves of biomass from energy crops, we focus on the long-term dynamic factors in the production costs. We postulate four factors that are relevant:

(a) land productivity;

(b) relative cost of labour and capital;

(c) innovations;

(d) land rental costs.

(a) Land productivity: The land productivity $Y$, in tonne or GJ per hectare(LHV $15 \mathrm{GJ} \mathrm{t}^{-1}$ ), is taken from [9] based on the IMAGE 2.2 scenarios, given on the basis of $0.5^{\circ} \times 0.5^{\circ}$ grid cells as a function of time.

(b) Relative cost of labour and capital: We assume that all inputs for the production process, next to land, can be incorporated in only two so-called production factors: capital input $\mathrm{K}$ and labour input $\mathrm{L}$. Let us also assume that the output $\mathrm{Y}$ is a Cobb-Douglass function of the required capital $\mathrm{K}$ and labour $L$ :

$\frac{Y}{Y_{0}}=\left(\frac{K}{K_{0}}\right)^{\alpha}\left(\frac{L}{L_{0}}\right)^{1-\alpha}$

with Y output per $\mathrm{km}$ (i.e. land productivity) $\left(\mathrm{TJ} \mathrm{km}^{-1} \mathrm{y}^{-1}\right), \alpha$ the capital-labour factor substitution elasticity $(0<\alpha<1)$ and $p_{i}$ the price of the corresponding factor $i$. The initial situation is associated with index 0 . Economic production theory suggests that there is an 'optimal' ratio between the use of capital and labour (e.g. [32]). It is given by

$\left(\frac{K}{L}\right)_{\text {opt }}=\left(\frac{\alpha}{1-\alpha}\right) \frac{p_{L}}{p_{K}}$

Thus, if the price of labour goes up-an increase in wages, that is-and the price of capital stays constant-a constant interest rate, that is-one would expect an increase in the capital-labour ratio as that would lower the total production costs. Behind such a process of substituting capital for labour is in fact a series of process changes, mechanisation being the most familiar one. These changes do not imply an increase in the overall productivity, but only a substitution of the labour and capital inputs.

In the agricultural sector, substitution of capital for labour has been known for decades. Recent examples have been published for Zimbabwe [33], South Africa [34] based on mechanisation of the harvesting and South Korea, mainly due to the introduction of biochemical technology [35]. This substitution effect may have quite an impact on the future cost of biomass-derived energy if labour wages rise significantly-to be expected in low-income regions with a significant income growth-and the availability and price of capital remain unchanged. It is not easy to give empirical evidence of such substitution and to derive a typical substitution coefficient. Data are scarce and often ill-defined. We present in Table 2 some estimated values based on empirical data from three countries. These data suggest that the substitution dynamics is indeed an existing phenomenon, because the resulting $p_{L} / p_{K}$ ratios are for a large range of $\alpha$ (0.45-0.95) and the (incorrect) assumption of similar capital cost indicating a wage ratio between the three countries of about 1:4.2:12.3 in the various countries at the time.

(c) Innovations: If the market for energy crops develops, one may expect cost-reducing and productivity increasing 
A1

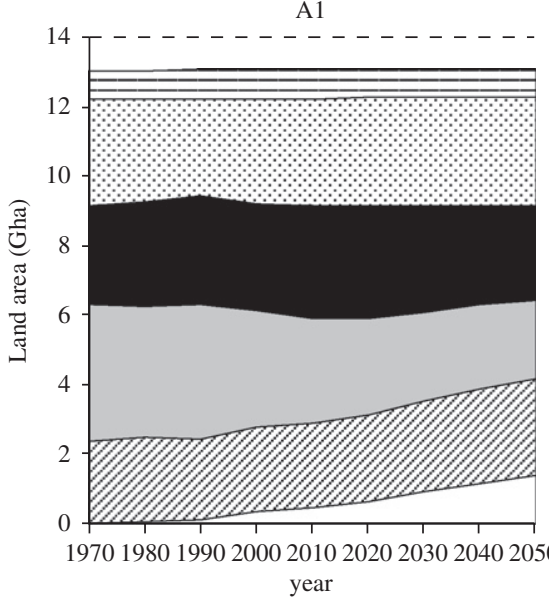

B1

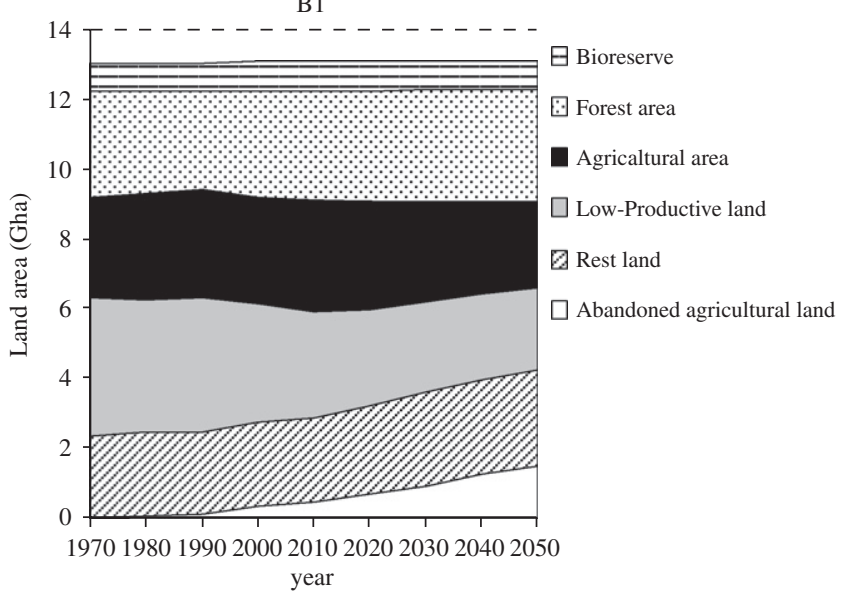

$\boxminus$ Bioreserve

‥ Forest area

Agricaltural area

$\square$ Low-Productive land

$\square$ Rest land

$\square$ Abandoned agricultural land
A2

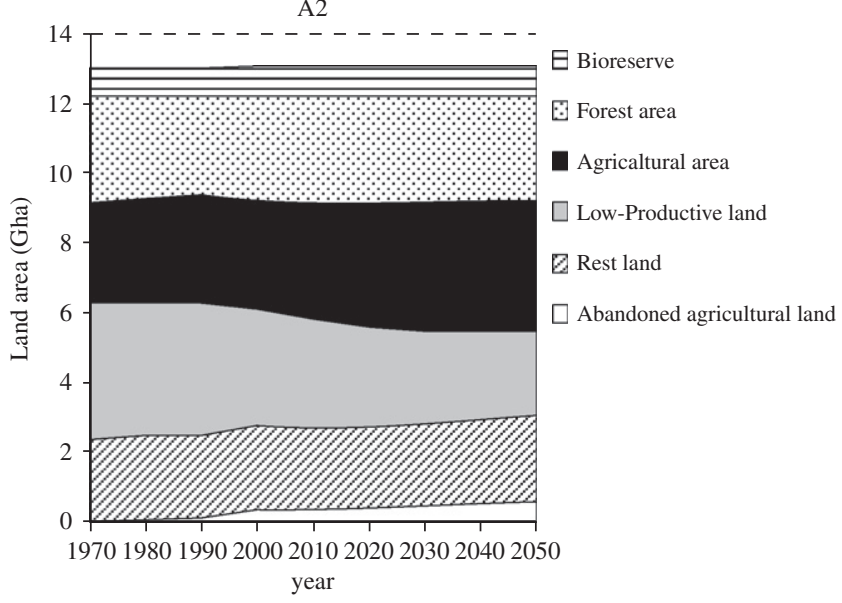

B2

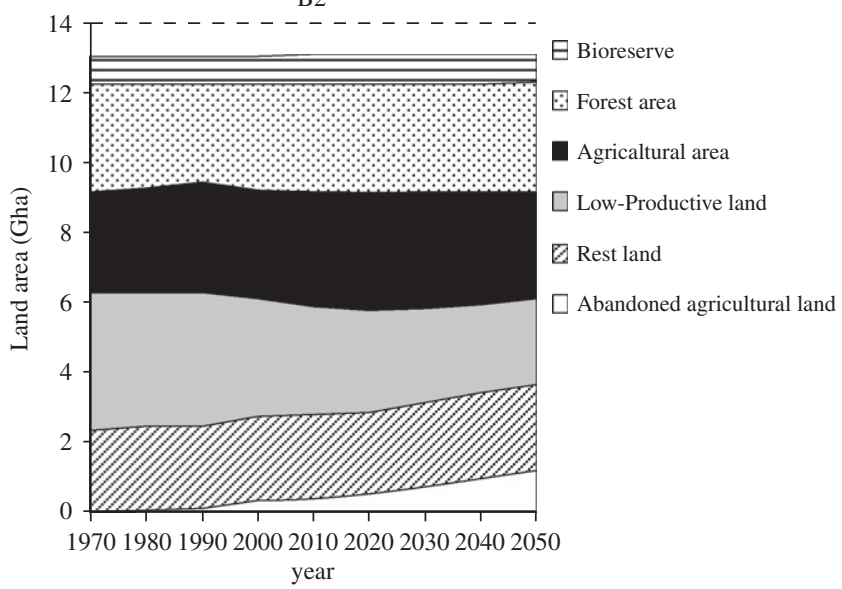

Fig. 1 - Variation of land cover over time for the four scenarios as simulated by IMAGE 2.2 [9].

Table 2 - The capital cost and labour cost (per ha and shares) of the production of three energy crops (data source: [36])

\begin{tabular}{|c|c|c|c|c|c|c|}
\hline \multirow[t]{2}{*}{ Plantation type } & \multicolumn{2}{|c|}{$\begin{array}{l}\text { Production cost } \\
\qquad\left(\$ \mathrm{ha}^{-1} \mathrm{yr}^{-1}\right)\end{array}$} & \multicolumn{2}{|c|}{$\begin{array}{l}\text { Factor share in production } \\
\text { cost }\end{array}$} & \multicolumn{2}{|c|}{$\begin{array}{c}p_{\mathrm{L}} / p_{\mathrm{K}} \text { ratio under assumption of } \\
\text { optimality }\end{array}$} \\
\hline & Capital & Labour & Capital & Labour & $\alpha=0.5$ & $\alpha=0.6$ \\
\hline Nicaragua (eucalyptus) & & & 0.66 & 0.34 & 1.94 & 1.29 \\
\hline Ireland (willow) & & & 0.89 & 0.11 & 8.09 & 5.39 \\
\hline The Netherlands (willow) & & & 0.96 & 0.04 & 24 & 16 \\
\hline
\end{tabular}

innovations. The actual trajectory for such cost reductions is impossible to predict, but there is evidence that technological learning evolves according to a log linear relationship of the form (see e.g. [37])

$\lambda=\left(\frac{\sum_{\mathrm{t}=0}^{\mathrm{t} O}}{\mathrm{O}_{0}}\right)^{\pi}$

with $\lambda$ the cost reduction factor with which the input of labour and capital are reduced, $\pi$ the learning coefficient $(\pi<0)$ and $O$ the output, or produced commodity. For simplicity we assume here so-called factor-neutral innovations, that is, it is not biased towards saving preferentially on the input of labour or capital as is the case in factor substitution. As we do not simulate actual use of bioenergy, but the potential availability over time, we assume that the production has the same development as the geographical potential, i.e. we use the geographical potential for the output. This approach to technological learning reflects the finding that some representative cost factors, e.g. input required per unit of output, tends to evolve linearly with the logarithm of cumulative production. The coefficient $\pi$ can also be expressed in the progress ratio $P R=2^{\pi}$. Please note that a progress ratio of 0.9 implies that the costs are reduced with 0.1 for each doubling of the cumulative production.

For each grid cell $i$, with a land productivity $Y_{i}\left(\mathrm{TJ} \mathrm{km}^{-2} \mathrm{y}^{-1}\right)$ and situated in region $r$, we propose the following expression for the cost calculation of the energy crop production 
costs $C_{i}\left(\$ G J^{-1}\right)$ :

$C_{i}=\frac{p_{K_{r}} \cdot \lambda_{r} \cdot K_{r}+p_{L_{r}} \cdot \lambda_{r} \cdot L_{r}+p_{A_{r}}}{Y_{i}}$

with $p_{K_{r}}$ the interest rate (-) and $p_{L_{r}}$ the price of labour (wages) (\$manyear ${ }^{-1} \mathrm{y}^{-1}$ ) in region $r ; p_{A_{r}}$ is the price of land in region $r$ $\left(\$ \mathrm{~km}^{-2} \mathrm{y}^{-1}\right)$ and $\lambda_{\mathrm{r}}$ the cost reduction factor due to technological learning in region $r . L_{r}$ is the required labour (manyear $\left.\mathrm{km}^{-2} \mathrm{y}^{-1}\right)$ and $K_{r}$ the required capital $\left(\$ \mathrm{~km}^{-2} \mathrm{y}^{-1}\right)$ in region $r$. It is assumed that labour and capital requirements are covering all the necessary operations and inputs in the production process.

From this formula it is seen that the local land productivity, regional labour wages, interest rate, land prices and cumulated production (geographical potential) are the determinants in our simple energy crop cost model. Note that, although in theory, land productivity is a function of the input ( $K$ and $L$ ), we use the land productivity from [9]: here $K$ and $L$ are calculated from the land productivity results. As $L$ and $K$ are increased with land productivity (intensification), the main reason for reduction is innovation and a decreased share of land costs (due to the variation in the ratio of land costs to land productivity). Among regions the variation in production costs is caused by a difference in cost reduction factors and land costs.

Fig. 2 illustrates the consequences of various assumptions with the example of a eucalyptus plantation in Nicaragua. The initial labour and capital inputs were derived from [6]. The exact value is rather uncertain, amongst others because we here have neglected the break-up costs. Curve 1 indicates the constant cost profile if cost inputs remain constant over time and no learning takes place. Let us first, for simplicity, assume that labour wages increase with $1 \%$ per timestep for a period of 100 timesteps. This leads to curve 2: an exponential rise in cost. If we include capital-labour substitution $(\alpha=0.65)$, curve 2 declines to curve 3, showing the effect of mechanisation and the like. Without capital-labour substitution but with factor-neutral innovations from technological learning, assuming a $1 \%$ production increase per timestep and a progress ratio 0.9 , costs will develop according to curve 4 . Finally, and still assuming the same $1 \%$ per timestep wage rise, curve 5 shows the cost trajectory with both substitution and learning. It is seen that one can postulate various mechanisms which influence future costs of energy crop derived energy-at least in theory.

Finally, cost-supply curves are constructed by ranking the geographical potential as a function of the estimated production costs in the grid cells.

\subsection{The cost-supply of secondary biomass: liquid fuel and bio-electricity}

The technical potential that accounts for the supply of secondary biomass is derived from [9]. Here we focus on the costs of secondary biomass energy. Consistent with [9] we investigate two distinct routes: conversion of woody biomass to liquid fuels (synthetic Fischer Tropsch (FT) diesel) and to electricity. Converting woody biomass into FT diesel, is assumed to include a gasification step. For the production of electricity, we assume that biomass gasification and subsequent combustion in combined cycle power plants is the preferred route as it is expected to have high efficiency and low electricity production cost in the long term $[27,38]$. These conversion technologies are not yet commercially available, but important technological improvements and commercialisation are expected by several authors [1,39-41].

To evaluate costs of liquid fuel or electricity derived from biomass in any given cell I, we postulate a standard conversion plant of technology $t$ with capacity $P(G) h^{-1}$ or $\mathrm{kW})$ and output $E_{\mathrm{t}}\left(\mathrm{GJy}^{-1}\right)$. The latter is the product of the load

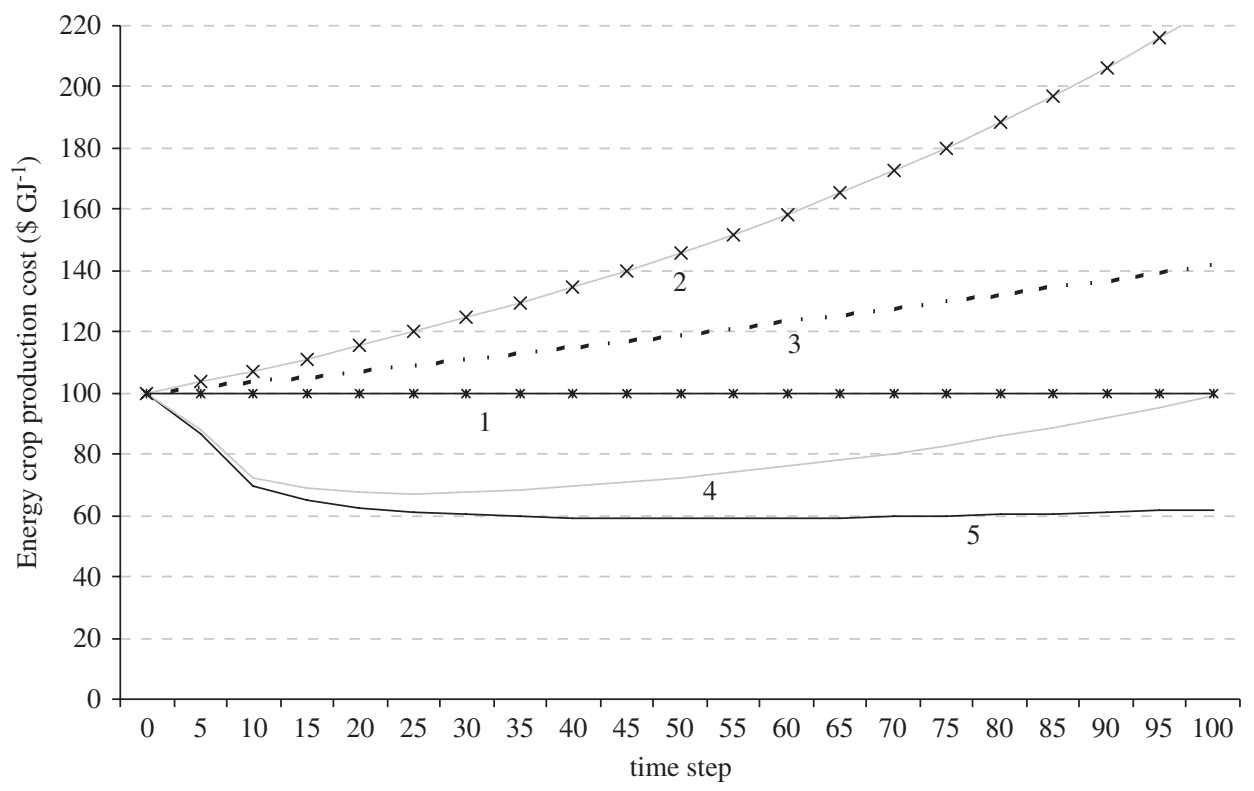

Fig. 2 - Development of energy crop production costs over time, applying different algorithms including constant wages (1), a $1 \%$ wage rise per timestep (2), substitution to reduce cost increase (3), innovations (4) or both substitution and innovations (5). The data are based on estimates for a plantation in Nicaragua, see text. 
factor (LF), the capacity $(P)$ and the amount of hours in a year. We have to account for four elements:

1. Primary biomass costs: These costs are obtained from the cost-supply curve of primary biomass and indicated by $p_{\mathrm{pb}}$.

2. Overall conversion efficiency: In the process from biomass to liquid fuel or electricity, losses will occur during transport and conversion resulting in an overall conversion efficiency $\eta$. As the transport losses at short distances are rather small [42], we take the plant conversion efficiency equal to the overall efficiency.

3. Transport from the harvesting area to the conversion plants: These costs can be approximated as the sum of fixed costs for loading/unloading, overhead, etc. of charter costs for trucks, etc. and for fuel costs as a function of the efficiency. It does not include costs for new road construction if good infrastructure is lacking. Transmission costs are not included in this analysis.

4. Capital cost and non-fuel operation and maintenance costs of the conversion plant: Unlike for biomass production, we neglect labour cost variation over time. Also we assume that operation and maintenance costs are a fixed fraction $\mu$ of the capital costs. The latter are annuitised by multiplying the specific investment costs with capacity $P$ and the annuity factor $a$. Annuitising is done in the usual way:

$a=\frac{r}{1-(1+r)^{-L}}$

with $r$ the interest rate, set at $10 \%$, and $L$ the economic lifetime, set at $20 \mathrm{yr}$. We assume the interest rate and economic lifetime of the conversion plants to be equal over the world and constant over time.

Of course, the cost of the conversion plant will change over time and probably decrease with increasing scale and experience (see e.g. $[38,43,44])$. Technological developments have been incorporated using the same learning curve as applied to the production of energy crops. Using this learning curve, we differentiate the specific investment costs among the four scenarios (different learning rate), regions and over time.

An overview of the calculations and input parameters used in this study is summarised in Fig. 3. The production cost of secondary biomass energy carriers produced in cell i $C_{\mathrm{sb}, \mathrm{i}}\left(\$ \mathrm{G}^{-1}\right)$, either liquid fuel or electricity, can now be expressed as

Csb, $i=\frac{E_{\mathrm{t}}\left(p_{\mathrm{pb}, \mathrm{i}}+\mathrm{T}+\mathrm{D} \tau F_{r} v\right)}{\eta}+\frac{(a+\mu \mathrm{t}) \cdot \mathrm{It} \cdot \mathrm{Pt}}{\mathrm{Et}}$

with $E_{\mathrm{t}}$ the plant output $\left(G \mathrm{Jy}^{-1}\right), p_{\mathrm{pb}, \mathrm{i}}$ the biomass feedstock cost, $T$ the fixed transport costs $\left(\$ G J^{-1}\right) ; D$ the distance, set at $50 \mathrm{~km}, \tau$ the transport or charter costs per unit of biomass, set at $\$ 0.0424 \mathrm{GJ}^{-1} \mathrm{~km}^{-1}, F_{r}$ the regional fuel costs $\left(\$ \mathrm{~m}^{-3}\right)$ and $v$ the fuel efficiency, accounting also for the load factor, set at $0.002 \mathrm{~m}^{3} \mathrm{GJ}^{-1}$

\section{Inputs to assess the production cost of energy crops}

The application of the methodology described in the previous section is done using data from the IMAGE 2.2 model and

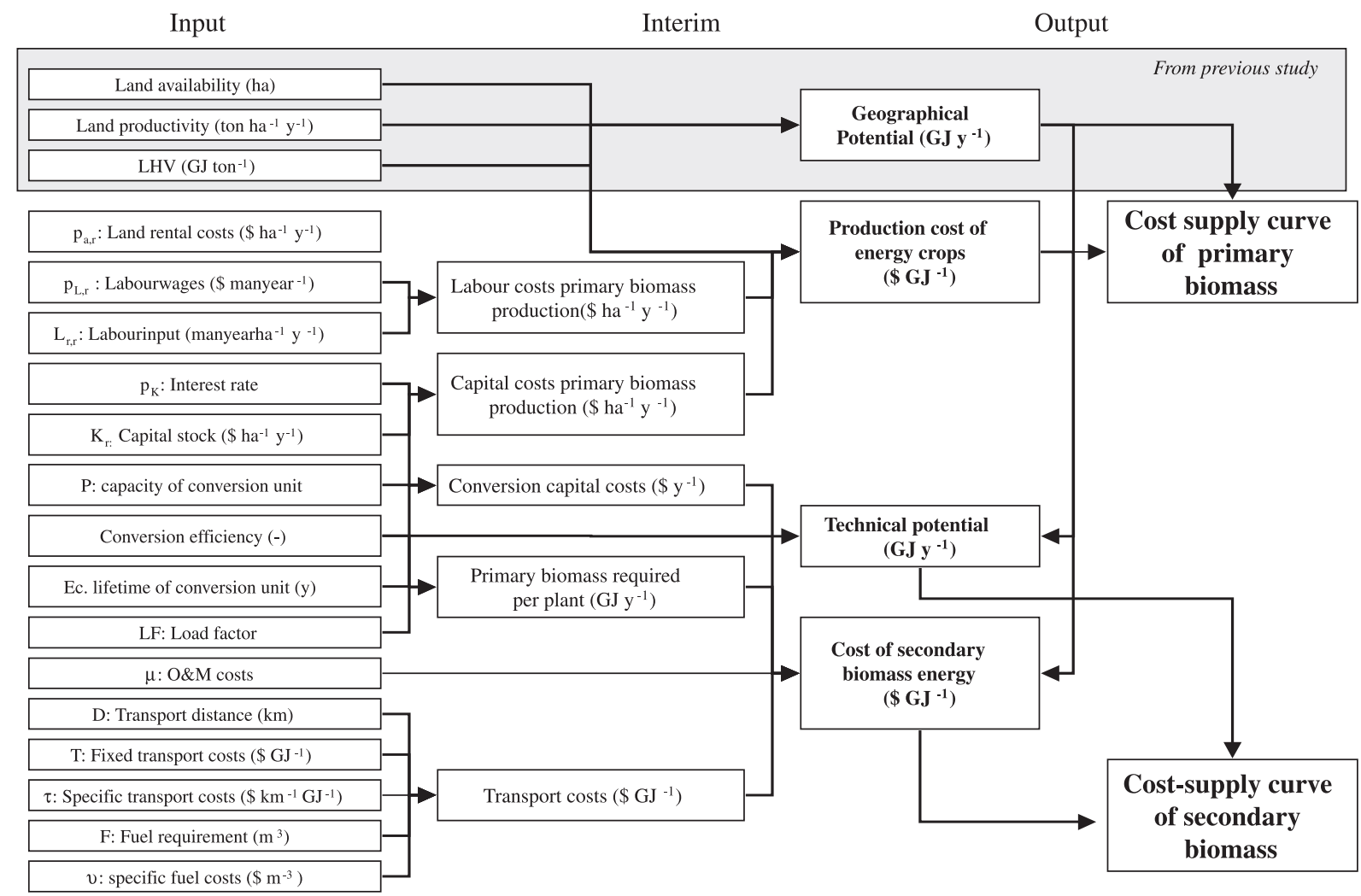

Fig. 3 - Overview of the approach to estimate the technical potential, the cost and the cost-supply curve of biomass for energy. This figure does not show the dynamics over time (capital-labour substitution and innovations). 


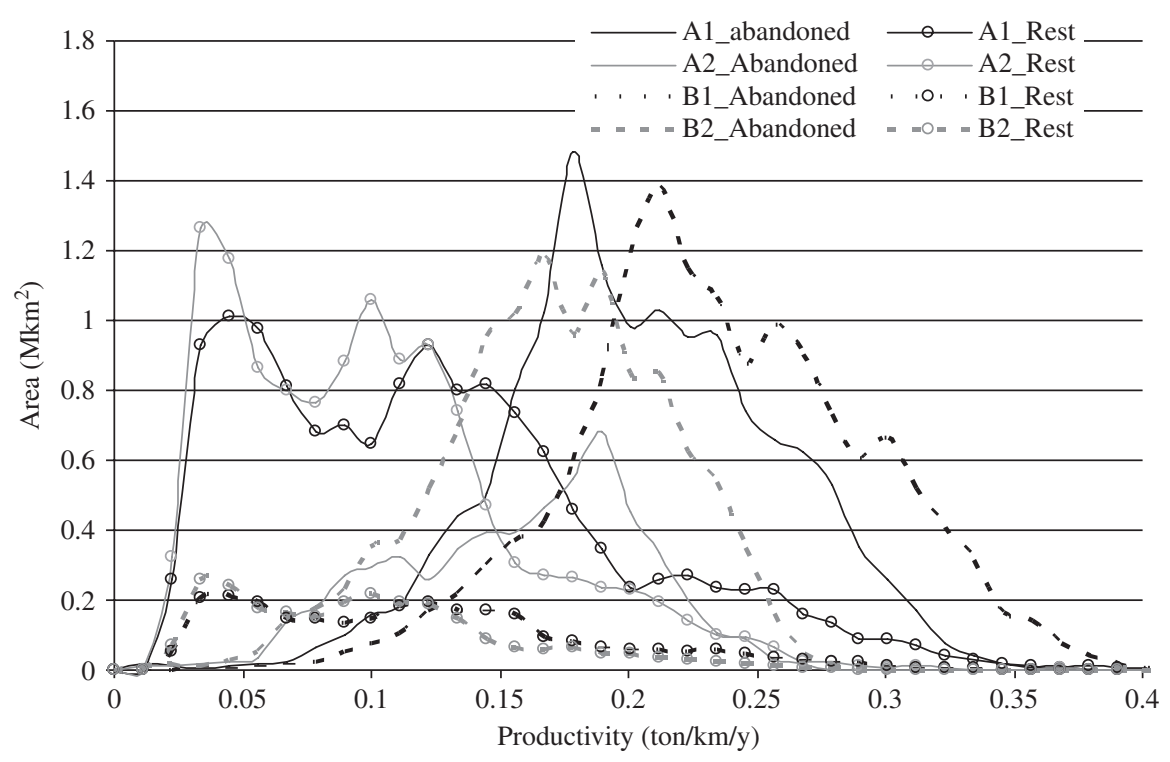

Fig. 4 - Available areas per land-use type for energy crop production and the distribution of the land productivity of energy crops at these areas for the four scenarios for the year 2050 [8].

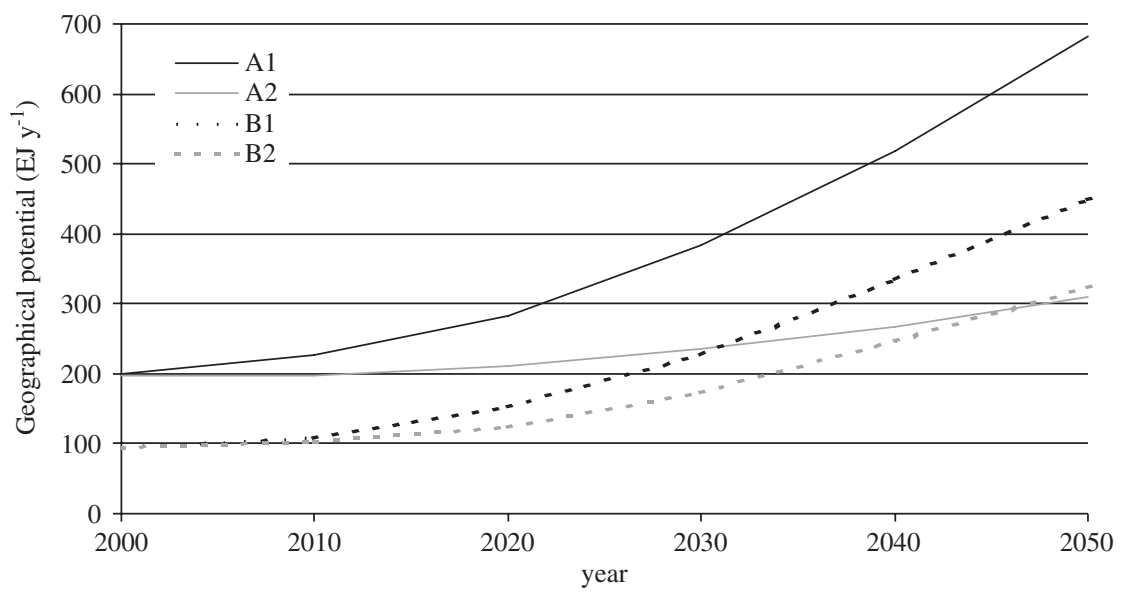

Fig. 5 - The global geographical potential of energy crops at abandoned agricultural land and rest land for four SRES scenarios between 2000 and 2050 [8].

from estimates based on literature review. The input data are described below.

\subsection{Land productivity and geographical potential}

The land productivity_or yield_of energy crops was obtained from calculations using the IMAGE 2.2 model at a grid cell level for each of the four land-use scenarios, taking into account soil quality and climatic indicators as precipitation, temperature and $\mathrm{CO}_{2}$ concentration. See [9] for an overview of the assumptions.

Given the land-use scenarios and the resulting potential for energy crops at abandoned agricultural land and rest land, we have ranked the cells available for energy crops in any year of the scenario-period according to their productivity. In Fig. 4 we present these distribution curves for the four scenarios for the year 2050. The curves show for instance that in the A2 scenario about $4 \times 10^{5}$ ha of abandoned agricultural land with a land productivity of between 1450 and $1550 \mathrm{tkm}^{-2} \mathrm{y}^{-1}$ can be maximally available for energy crop production in 2050. It is seen that in scenarios A1 and B1 quite a large area of productive land may become available in principle; in the other two scenarios it is less. Clearly, the rest land area is large but its low productivity makes it much less attractive. Fig. 5 shows the development of the calculated geographical potential between 2000 and 2050 for the four scenarios. The main difference between the A1, A2 scenarios and the B1, B2 scenarios concerning the geographical potential originates from the assumed differences in land-claims for nature development between the scenarios.

\subsection{Land rental cost}

A second component in the calculation of primary biomass cost is the cost for land rental in region $r, p_{A_{r}}\left(\$ \mathrm{~km}^{-2} \mathrm{y}^{-1}\right)$. It depends on many local factors, such as the quality of land, 
the demand for land, subsidies and the distance to infrastructure. There is no unambiguous way of constructing a regional average from the-scarce-local data. The values mentioned in the literature (see below), give an indication of the ranges. Assuming a productivity of on average $15 \mathrm{TJ} \mathrm{km} \mathrm{km}^{-2} \mathrm{y}^{-1}$, the land costs may range from $\$ 0.1$ to $4 \mathrm{GJ}^{-1}$.

We propose an estimation of land rental costs based on data on the added value of land from the World Bank [45]. The added value of land is estimated as the difference between the (global) market value of the output crops and the cropspecific production costs, using market values and production costs of cereal, maize and rice. The data from [45] have been allocated to the regional division of IMAGE 2.2 and also used to estimate changes over time. Because we assume biomass to be planted on land no longer required for food production and, hence, on relatively low productive land compared to agricultural land, the World Bank estimates will be too high. In an earlier study with the IMAGE model [46], they were multiplied with the ratio of the lowest productivity of the crop produced mostly in the region and the regional average productivity of that crop. This approach is also adopted here. These ratios were estimated in order of 0.2-0.6, varying among regions and changing over time if crop distribution changes. This ratio is in some regions low, assuming that land quality contributes significantly to the land price. This is a simplification that is expected to lead to an underestimation of land price. However, due to the complexity of the land price dynamics, we have only included this factor. The resulting estimated cost of land for the 17 IMAGE regions used in this study are shown in Table 3. They are fairly similar to the values from literature for most developing regions and North America; however, they are low compared to OECD Europe. Land rental costs in the literature for agricultural or energy crop land are found ranging from 1600 to $9500 \$_{2000} \mathrm{~km}^{-2} \mathrm{y}^{-1}$ in Africa [46], 2700 to $15,000 \$_{2000} \mathrm{~km}^{-2} \mathrm{y}^{-1}$ in Latin America $[6,28,46], 1500-23,600 \$_{2000} \mathrm{~km}^{-2} \mathrm{y}^{-1}$ in North America $[10,19$, $26,28,47]$ and from 3600 to $64,800 \$ 2000 \mathrm{~km}^{-2} \mathrm{y}^{-1}$ in Europe $[26,47-52]$.

\subsection{Capital, labour cost, substitution coefficient and learning}

For the energy crop plantations, we assume that the expenses in the form of seeds or cuttings, machines required for planting, plowing or harvesting and fertilisers and weed control can all be incorporated in a single cost figure: the annuitised capital costs. Because of regional differences and differences in production system these costs can vary significantly. Currently observed costs of cuttings, for instance, range from $\$ 0.01$ to 0.1 cutting $^{-1}$, with cutting densities for willow plantations at a level of $10 \times 10^{5}-16 \times$ $10^{5}$ cuttings $\mathrm{km}^{-2}[6,53]$. Operational costs during the production are to a large extent determined by the cost of fertiliser and fertilisation management. Pesticides and herbicides are less intensely used, mostly for the production of cuttings, e.g. [54]. Because fertilisation depends strongly on soil quality, there is a wide range in estimates for the amount of fertilisation required. Estimates range from 900 to $15,000 \mathrm{~kg} \mathrm{~km}^{-2} \mathrm{y}^{-1}$ for $\mathrm{N}$, 200 to $9000 \mathrm{~kg} \mathrm{~km}^{-2} \mathrm{y}^{-1}$ for $\mathrm{P}$ and $700-9000 \mathrm{~kg} \mathrm{~km}^{-2} \mathrm{y}^{-1}$ for $\mathrm{K}$ $[19,29,55-58]$. The actually applied fertiliser can have a signifi- cant impact on land productivity. Fertiliser costs range from 0.4 to $1.6 \$ 2000 \mathrm{~kg}^{-1}[25,48]$. Using application levels as presented above, this results in costs per hectare of between 80 and $24,000 \$_{2000} \mathrm{~km}^{-2} \mathrm{y}^{-1}$. Assuming an average productivity of $15 \mathrm{TJ} \mathrm{km}{ }^{-2} \mathrm{y}^{-1}$, which might be overestimated for the low and underestimated for the high input case, fertilisation costs range from $\$ 0$ to $1.6 \mathrm{GJ}^{-1}$. In our calculations we estimated the required capital from the labour costs and the capital-labour ratio, based on initial values of these labour and capital costs, based on [54].

Another important cost determinant is the price of capital, i.e. the interest rate. It is project-specific and depends on factors such as access to capital markets, project risk appraisal and credit facilities. We use a fixed interest rate of $10 \%$ for all regions, the same value as that used in the IMAGE 2.2 simulations [14].

The third important cost component is labour costs. These are a function of the required labour input and the labour wages. The wages differ for high-skilled and low-skilled labour. Average of high- and low-skilled labour wages per hour (assuming $8 \mathrm{~h}$ of work per day) found in the literature are about $12 \$_{2000} \mathrm{~h}^{-1}$ in Finland [50], about $13 \$_{2000} \mathrm{~h}^{-1}$ in the USA [59], about $0.3 \$_{2000} \mathrm{~h}^{-1}$ in Nicaragua and $12.8 \$_{2000} \mathrm{~h}^{-1}$ in Ireland [6]. In view of our model formulation, wage changes matter mostly and we use the development of regional gross domestic product (GDP) $\mathrm{cap}^{-1}$ as a proxy of the labour wages (see Table 3).

For all regions, the capital-labour substitution elasticity is set at 0.65 , based on the data presented in Table 2. For the initial labour and capital input we use the cross-country analysis from Table 2 . We have divided the regions in three groups according to their GDP value in the year 2000. The Netherlands is assumed to be representative for the regions with the highest GDP, Ireland for the middle class and Nicaragua for the lowest category.

For the assessment of the progress ratio, it is assumed that in the scenarios with a higher gross world productivity and more global oriented (A1 and $\mathrm{B} 1$ ), the progress ratio is 0.9 . For the other scenarios (A2 and B2), it is assumed that learning is less fast due to lack of investments and lower cross-country innovations; the progress ratio is set at 0.95 . We assume the progress ratio to be constant over time. This may be in contrast to what is suggested in the literature about decreasing progress ratios (e.g. [37]) but we found too little empirical evidence for time dependency of learning.

\subsection{Transportation cost}

Another cost component is transport from land of production to conversion unit. There are various aspects that determine the transport costs, at first the transport distance. The transport distance is a function of the size of the conversion unit and the supply around the conversion unit. This has been analysed in various studies, e.g. $[29,44]$. The distance is the main reason for the choice of the type of transport medium. Truck transport is mostly favoured at short distances $<150 \mathrm{~km}[60,61]$. Furthermore, the transport costs depend on the load that can be transported (e.g. chips versus logs), also on the return trip and the car efficiency. The product of these factors and the fuel prices determines the 
Table 3 - The regional transport cost, the regional labour and the regional annual land cost estimated in this study, using the IMAGE 2.2 model based on land value figures from the World Bank [44]

\begin{tabular}{|c|c|c|c|c|c|c|c|c|c|}
\hline & \multirow[t]{2}{*}{ Transport costs $\left(C_{t}\right)\left(\$ G J^{-1}\right)$} & \multicolumn{4}{|c|}{ Labour cost $\left(p_{\mathrm{L}}\right)\left(\$ \mathrm{~h}^{-1}\right)$} & \multicolumn{4}{|c|}{ Land cost $\left(p_{A_{r}}\right)\left(\$ \mathrm{~km}^{-2} \mathrm{yr}^{-1}\right)$} \\
\hline & & $\begin{array}{c}\text { A1 } \\
2000-2050\end{array}$ & $\begin{array}{c}\text { A2 } \\
2000-2050\end{array}$ & $\begin{array}{c}\text { B1 } \\
2000-2050\end{array}$ & $\begin{array}{c}\text { B2 } \\
2000-2050\end{array}$ & $\begin{array}{c}\text { A1 } \\
2025-2050\end{array}$ & $\begin{array}{c}\text { A2 } \\
2025-2050\end{array}$ & $\begin{array}{c}\text { B1 } \\
2025-2050\end{array}$ & $\begin{array}{c}\text { B2 } \\
2025-2050\end{array}$ \\
\hline Canada & 0.33 & $12.6-26.4$ & $12.5-18.2$ & $12.6-26.4$ & $12.5-21.9$ & $0.64-0.68$ & $0.65-0.67$ & $0.64-0.65$ & $0.65-0.67$ \\
\hline USA & 0.31 & $18.6-43.2$ & $18.5-28.4$ & $18.6-35.6$ & $18.5-34.7$ & $1.55-1.55$ & $1.47-1.55$ & $1.41-1.98$ & $1.50-1.53$ \\
\hline Central America & 0.29 & $1.7-15.5$ & $1.6-5.9$ & $1.7-13.7$ & $1.7-7.0$ & 1.37-1.19 & $1.45-1.23$ & $1.19-1.37$ & $1.44-1.24$ \\
\hline South America & 0.29 & $2.7-20.6$ & $2.7-8.1$ & $2.7-18.2$ & $2.7-9.7$ & $1.16-1.27$ & $1.26-1.30$ & $1.16-1.20$ & $1.23-1.27$ \\
\hline North Africa & 0.4 & $0.8-9.4$ & $0.8-3.3$ & $0.8-8.3$ & $0.8-4.2$ & $0.26-0.31$ & $0.26-0.25$ & $0.26-0.27$ & $0.26-0.31$ \\
\hline Western Africa & 0.4 & $0.2-2.6$ & $0.2-0.8$ & $0.2-2.5$ & $0.2-1.0$ & $0.22-0.23$ & $0.23-0.23$ & $0.22-0.23$ & $0.23-0.24$ \\
\hline Eastern Africa & 0.4 & $0.1-2.2$ & $0.1-0.7$ & $0.1-2.2$ & $0.1-0.8$ & $0.20-0.21$ & $0.22-0.21$ & $0.21-0.22$ & $0.21-0.22$ \\
\hline South Africa & 0.31 & $0.7-6.0$ & $0.7-2.2$ & $0.7-6.0$ & $0.7-2.5$ & $0.93-0.70$ & $0.75-1.02$ & $0.65-0.92$ & $0.8-1.02-80$ \\
\hline Western Europe & 0.45 & $14.1-36.9$ & $14.1-22.5$ & $14.1-31.8$ & $14.2-27.5$ & $1.30-1.31$ & $1.24-1.35$ & $1.27-1.32$ & $1.33-1.40$ \\
\hline Eastern Europe & 0.38 & $2.0-23.9$ & $1.9-7.0$ & $2.0-14.0$ & $2.0-12.5$ & $0.72-0.66$ & $0.71-0.73$ & $0.70-0.72$ & $0.71-0.73$ \\
\hline Former USSR & 0.38 & $1.0-16.9$ & $0.9-3.8$ & $1.0-10.8$ & $1.0-7.9$ & $0.29-0.24$ & $0.29-0.29$ & $0.28-0.29$ & $0.29-0.29$ \\
\hline Middle East & 0.31 & $2.1-16.6$ & $2.1-6.2$ & $2.1-14.6$ & $2.1-7.9$ & $0.30-0.30$ & $0.30-0.31$ & $0.29-0.31$ & $0.30-0.31$ \\
\hline South Asia & 0.31 & $0.3-6.4$ & $0.2-1.0$ & $0.3-4.3$ & $0.3-3.1$ & $1.11-1.47$ & $1.09-1.48$ & $1.07-147$ & $1.14-1.18$ \\
\hline East Asia & 0.32 & $1.1-18.0$ & $1.0-2.9$ & $1.1-10.3$ & $1.1-9.8$ & $4.06-1.69$ & $1.40-1.44$ & $1.63-166$ & $4.17-4.19$ \\
\hline South-East Asia & 0.26 & $0.9-11.0$ & $0.9-2.6$ & $0.9-7.1$ & $0.9-7.8$ & $1.55-1.49$ & $1.81-1.49$ & $1.51-153$ & $1.50-1.56$ \\
\hline Oceania & 0.26 & $10.2-25.8$ & $10.2-14.6$ & $10.2-22.1$ & $10.2-18.2$ & $0.13-0.13$ & $0.14-0.14$ & $0.13-0.14$ & $0.13-0.14$ \\
\hline Japan & 0.37 & $25.2-48.1$ & $25.1-34.0$ & $25.2-38.4$ & $25.5-39.5$ & $6.28-7.37$ & $6.55-6.48$ & $5.40-8.13$ & $4.89-4.91$ \\
\hline World & & $5.5-19.6$ & $5.5-9.5$ & $5.5-15.7$ & $5.5-12.7$ & $1.30-1.22$ & $1.16-1.19$ & $1.12-1.25$ & $1.23-1.24$ \\
\hline
\end{tabular}


fuel costs per transported commodity. For the USA it was shown that in the past 30 years the overall efficiency in $\mathrm{MJ}^{-1} \mathrm{~km}^{-1}$ has increased significantly, mainly due to an increase in transport load [62]. In addition, there are costs for loading and unloading. These fixed costs depend on the type of biomass transported and the labour costs. Finally, there are charter costs, accounting for the truck rent. As the locations of the plants are not fixed and we do not have information on the distribution of the energy plantations within grid cells, such detailed analysis of transport distances cannot be conducted. Instead we use a fixed illustrative average transportation distance of $50 \mathrm{~km}$, which lies in the range found in the literature for national transportation of biomass $(20-80 \mathrm{~km})[12,26,63,64]$. The distance of $50 \mathrm{~km}$ can be outside the grid cell size used in the land-use simulations. The value was chosen as it represents the distance in real. The exact distance chosen does not have a large influence on the final costs. We use a formulation for the transport costs $\left.C_{t}(\$ G)^{-1}\right)$ and the parameters that are based on Northern European data [60] (see also Eq. (5)):

$C_{t}=T+\tau D \tau F_{r} v$

Fuel costs are available for a large range of countries [65]: the other parameters are more difficult to determine. One can argue that fixed and charter costs are lower in regions with relatively low wages. However, at the same time, the fuel requirement is often higher. We therefore calculated the transport costs by only varying the fuel costs as a first approach. This results in a range in transport costs at a national level of 0.26 (New Zealand) to $\$ 0.6 \mathrm{GJ}^{-1}(\mathrm{UK})$. The fuel costs are for a significant share determined by taxes [62]. No data for African countries are included in this range. We assume that the regions distinguished in this study have transport costs based on the averages of the national ranges. For African regions, we assumed similar costs as in the Former USSR and East Europe because these are average costs and we assume low-quality roads and low car efficiency. The transport costs at regional level are given in Table 3. Due to lack of data, in the long term it is assumed that the transport cost remains constant.

Various studies conclude that international trade in biomass or energy carriers derived from biomass, such as liquid fuels, can be an interesting option, for instance between regions with limited resources but renewable energy targets and regions with ample supply of biomass $[60,64]$. At present biomass is also traded at significant levels, e.g. [61]. The cost of such inter-regional transport is excluded in this study.

\subsection{Conversion to liquid fuel and bioelectricity}

The cost-supply curve for the secondary biomass-derived liquid fuel and electricity requires data on the performance of the conversion plants such as the overall conversion efficiency $\left(\eta_{t}\right)$, specific investment costs and the like. The assumptions regarding these variables are based on various sources, e.g. $[38,39,42]$, and are given in Table 4 . They are taken as being equivalent across all regions. One can assume that similar technological learning takes place as was assumed for the production of energy crops, reducing the specific investment costs. We therefore use the same cost
Table 4 - Summary of the values of the parameters used in the cost calculations of different conversion technologies

\begin{tabular}{|c|c|c|}
\hline & $\begin{array}{l}\text { Biomass } \\
\text { electricity }\end{array}$ & $\begin{array}{l}\text { Biomass } \\
\text { transport fuel }\end{array}$ \\
\hline $\begin{array}{l}\text { Conversion route/type of } \\
\text { fuel }\end{array}$ & $\begin{array}{l}\text { Gasification } \\
\text { combined cycle }\end{array}$ & $\begin{array}{l}\text { Gasification FT } \\
\text { conversion }\end{array}$ \\
\hline Typical scale (MWth) ${ }^{\mathrm{a}}$ & $20-1000$ & $100-2000$ \\
\hline Status & Demonstration & $\begin{array}{l}\text { Laboratory/ } \\
\text { demonstration }\end{array}$ \\
\hline $\begin{array}{l}\text { Conversion efficiency (\%) } \\
\text { (year 2000) }\end{array}$ & 40 & 40 \\
\hline $\begin{array}{l}\text { Conversion efficiency (\%) } \\
\text { (year 2050) }\end{array}$ & 56 & 55 \\
\hline Availability (\%) & 95 & 95 \\
\hline Load factor ${ }^{c}$ & 0.7 & 0.8 \\
\hline $\begin{array}{l}\text { Specific investment costs } \\
\left(\$ \mathrm{~kW}^{-1}\right) \text { (year 2000) }\end{array}$ & 1370 & 1630 \\
\hline \multirow[t]{2}{*}{$\begin{array}{l}\text { Specific investment costs } \\
\left(\$ \mathrm{~kW}^{-1}\right) \text { (year 2050) }\end{array}$} & A1, B1: 1120 & A1, B1: 1180 \\
\hline & A2, B2: 1300 & A2, B2: 1380 \\
\hline $\begin{array}{l}\text { Operational and } \\
\text { maintenance costs (\% of } I \text { ) }\end{array}$ & 4 & 4 \\
\hline Lifetime technology (yr) & 20 & 20 \\
\hline \multicolumn{3}{|c|}{$\begin{array}{l}\text { a We used typical scales mentioned in the literature for present } \\
\text { plants and future plants. } \\
\text { b The production of synthetic diesel by Fischer Tropsch technology } \\
\text { using biomass is in the pilot scale; however, the conversion of coal } \\
\text { to Fischer Tropsch oil is commercial already. } \\
{ }^{{ }^{2}} \text { The load factor is defined as the ratio between the full-load hours } \\
\text { per year and the total amount of hours in a year ( } 8760) \text {. }\end{array}$} \\
\hline
\end{tabular}

reduction factors as calculated for energy crop production. The initial investment costs are based on figures as found in the literature, representative for a biomass integrated gasification combined cycle (BIGCC) plant of about $200 \mathrm{MW}$ and a FT plant of about $500 \mathrm{MW}$. One of the ways to achieve cost reductions is scaling up. The cost reductions assumed here can be reached using a scale of about $300 \mathrm{MW}$ for BIGCC and about $1000 \mathrm{MW}$ for FT. For BIGCC this estimate is based on a scale relation using a reference plant of $50 \mathrm{MW}$ with an investment cost of $\$ 2400 \mathrm{~kW}^{-1}$ and a scaling factor of -0.4 [39]. For FT, these investment costs are based on a scale relation using a reference plant of $400 \mathrm{MW}$ with an investment cost of $\$ 1530 \mathrm{~kW}^{-1}$ and a scaling factor of -0.22 [43]. One may argue that further cost reduction is possible, e.g. by increasing the size of the conversion pant. However, as at present both technologies are not available at commercial basis, we rather use these, possibly more conservative figures.

\section{The cost-supply curves of primary biomass energy}

The production costs of energy crops develop over time. They may increase because of increasing labour costs. Over time, the production costs will fall due to technological learning at a regional level. An example is given in Fig. 6. Note the differences between the two scenarios (A1 and A2). 

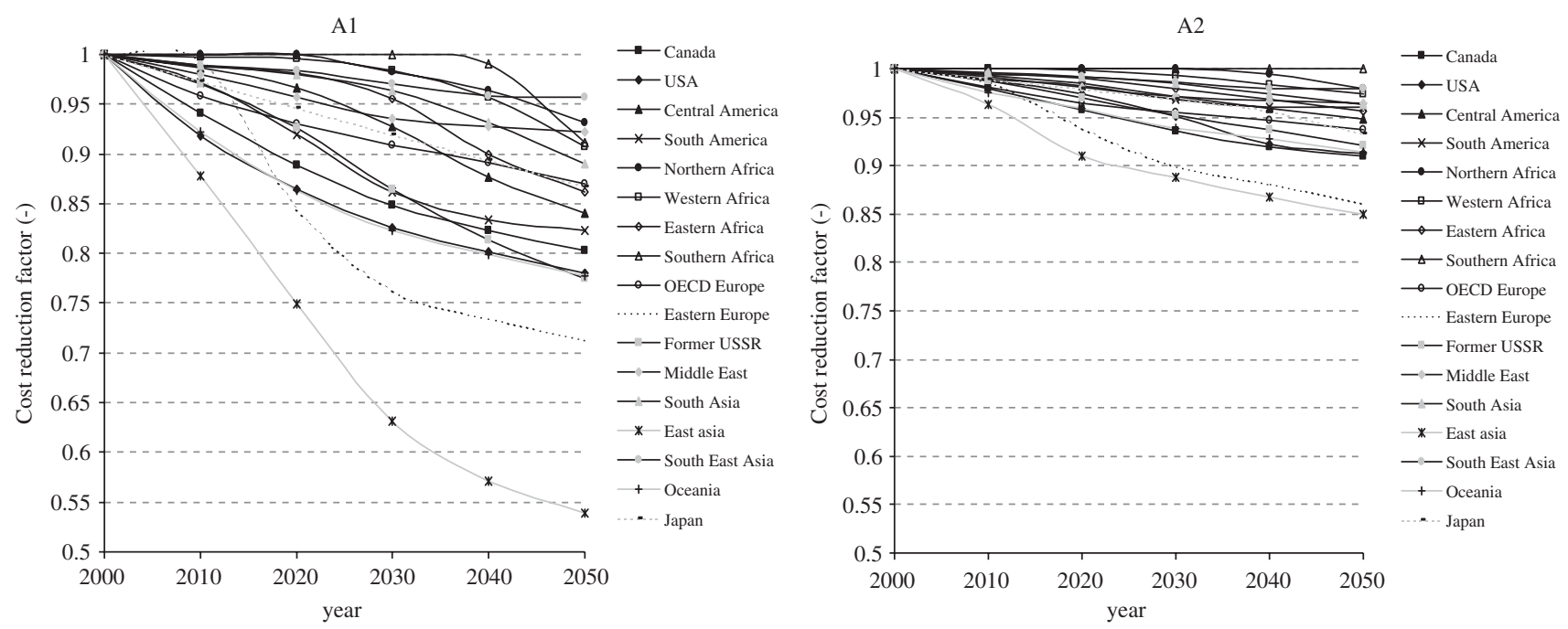

Fig. 6 - The cost reduction factor $(\lambda)$ for capital and labour costs for the production of energy crops that takes into account the technological learning for the A1 and A2 scenarios.

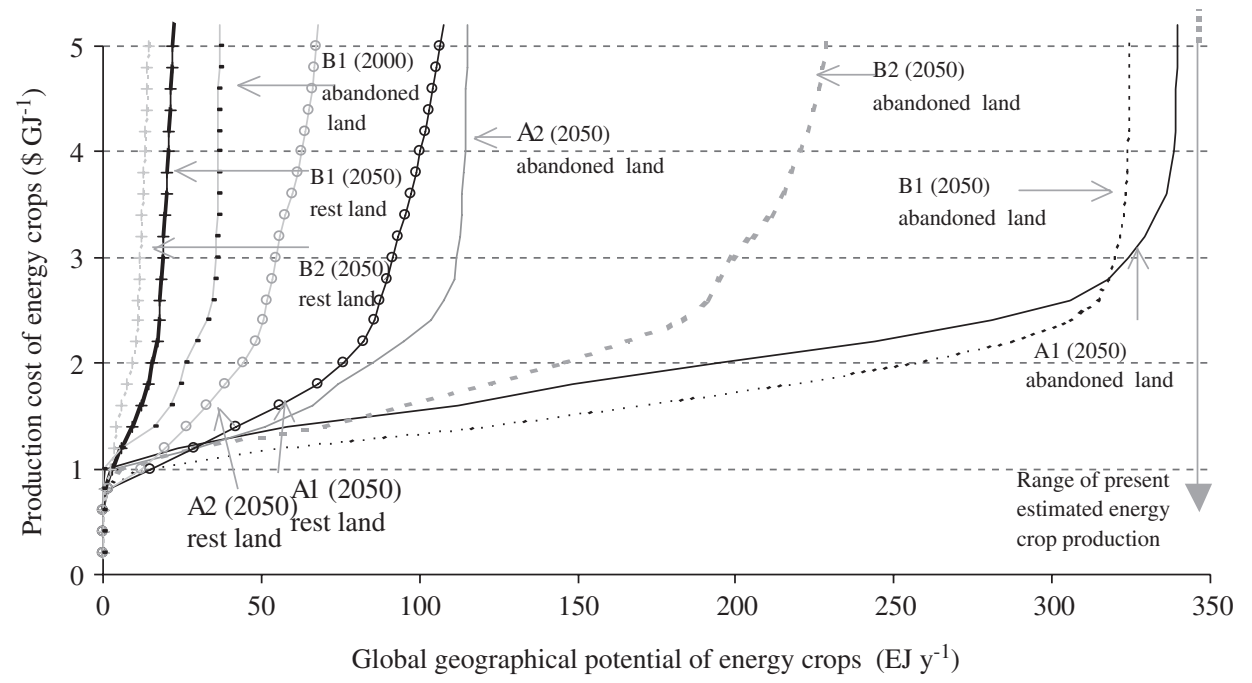

Fig. 7 - The global average cost-supply curve for the production of energy crops for four SRES scenarios for the year 2050 and the cost-supply curve at abandoned agricultural land for the year 2000 for the B1 scenario is also shown.

The variation between the regions is comparable for the two scenarios, but the A1 scenario has larger reduction factors due to the larger geographical potential over time. In both scenarios, East Asia and Eastern Europe have the highest cost reduction potential. Note that technological learning is influenced by the overall geographical potentials as functions of time and by the progress ratio, but also by the geographical potential in the initial situation, here chosen as the year 2000. This is the reason why for instance the Former USSR, the region with the highest potential, does not have the largest estimated cost reduction; this occurs in Eastern Africa for both scenarios.

The global cost-supply curves of energy crops at abandoned agricultural land and at rest land for four Special Report on Emission Scenarios (SRES) scenarios in the year 2050 are shown in Fig. 7. Technological learning and capital-labour substitution in response to rising income, e.g. wage levels, are included. Also for the B1 scenario, the cost-supply curve for the year 2000 for abandoned agricultural land is shown. One should realise that these potentials not only depend on cost parameters but also on the time-dependent geographical potential (Fig. 7). Therefore, the two scenarios with the lowest value of the progress ratio (highest technology-induced cost reductions) and the highest geographical potentials have the lowest energy crop production costs, A1 and B1. The cost-supply curves lie for a significant part, i.e. 130 (A2)-270 (A1) $\mathrm{EJ}^{-1}$ below $\$ 2 \mathrm{GJ}^{-1}$ which is considered the lower level of the present (2005) price for coal [69]. The lowest costs found for the year 2000 are $\$ 1 \mathrm{GJ}^{-1}$. For 2050 , the lowest costs are found at $\$ 0.8 \mathrm{GJ}^{-1}$, in the A1 scenario in Eastern Africa.

The results obtained for both land types together at the regional level are presented in Table 5. It is found that Eastern and Western Africa has the lowest-cost largest potential (below $\$ 1 \mathrm{GJ}^{-1}$ ). Regions that are assumed to be able to produce significantly at costs below $\$ 2 \mathrm{GJ}^{-1}$ are the Former USSR, Oceania, West and East Africa. 
Table 5 - The total estimated geographical potential of energy crops for the year 2050, at abandoned agricultural land and rest land and the estimated geographical

potential at various cut-off costs for the four land-use scenarios

\begin{tabular}{|c|c|c|c|c|c|c|c|c|c|c|c|c|c|c|c|c|}
\hline \multirow[t]{2}{*}{ Region } & \multicolumn{4}{|c|}{ A1 } & \multicolumn{4}{|c|}{ A2 } & \multicolumn{4}{|c|}{ B1 } & \multicolumn{4}{|c|}{ B2 } \\
\hline & $\begin{array}{l}\text { Below } \\
\$ 1 \mathrm{GJ}^{-1}\end{array}$ & $\begin{array}{l}\text { Below } \\
\$ 2 G^{-1}\end{array}$ & $\begin{array}{l}\text { Below } \\
\$ 4 \mathrm{GJ}^{-1}\end{array}$ & $\begin{array}{c}\text { Geographical } \\
\text { potential } \\
\left(\mathrm{EJ} \mathrm{yr}^{-1}\right)\end{array}$ & $\begin{array}{l}\text { Below } \\
\$ 1 \mathrm{GJ}^{-1}\end{array}$ & $\begin{array}{l}\text { Below } \\
\$ 2 G J^{-1}\end{array}$ & $\begin{array}{l}\text { Below } \\
\$ 4 \mathrm{GJ}^{-1}\end{array}$ & $\begin{array}{l}\text { Geographical } \\
\text { potential } \\
\left(\mathrm{EJ} \mathrm{yr}^{-1}\right)\end{array}$ & $\begin{array}{l}\text { Below } \\
\$ 1 \mathrm{GJ}^{-1}\end{array}$ & $\begin{array}{l}\text { Below } \\
\$ 2 \mathrm{G}^{-1}\end{array}$ & $\begin{array}{l}\text { Below } \\
\$ 4 \mathrm{GJ}^{-1}\end{array}$ & $\begin{array}{c}\text { Geographical } \\
\text { potential } \\
\left(\mathrm{EJyr}^{-1}\right)\end{array}$ & $\begin{array}{l}\text { Below } \\
\$ 1 \mathrm{GJ}^{-1}\end{array}$ & $\begin{array}{l}\text { Below } \\
\$ 2 G^{-1}\end{array}$ & $\begin{array}{l}\text { Below } \\
\$ 4 \mathrm{GJ}^{-1}\end{array}$ & $\begin{array}{c}\text { Geographical } \\
\text { potential } \\
\left(\mathrm{EJ} \mathrm{Jr}^{-1}\right)\end{array}$ \\
\hline Canada & 0.0 & 11.4 & 14.3 & 18 & 0.0 & 7.9 & 9.4 & 12 & 0.0 & 11.1 & 12.1 & 14 & 0.0 & 10.0 & 11.1 & 13 \\
\hline USA & 0.0 & 17.8 & 34.0 & 53 & 0.0 & 6.9 & 18.7 & 33 & 0.0 & 24.5 & 32.9 & 36 & 0.0 & 27.6 & 39.4 & 49 \\
\hline $\begin{array}{l}\text { Central } \\
\text { America }\end{array}$ & 0.0 & 7.0 & 13.0 & 17 & 0.0 & 2.0 & 2.9 & 4 & 0.0 & 4.1 & 7.6 & 11 & 0.0 & 1.6 & 3.3 & 5 \\
\hline $\begin{array}{l}\text { South } \\
\text { America }\end{array}$ & 0.0 & 11.7 & 73.5 & 87 & 0.0 & 5.3 & 14.8 & 24 & 0.0 & 27.6 & 60.7 & 63 & 0.0 & 6.1 & 32.7 & 43 \\
\hline $\begin{array}{l}\text { Northern } \\
\text { Africa }\end{array}$ & 0.0 & 0.9 & 2.0 & 5 & 0.0 & 0.7 & 1.3 & 4 & 0.0 & 0.7 & 1.5 & 3 & 0.0 & 0.7 & 1.0 & 2 \\
\hline $\begin{array}{l}\text { Western } \\
\text { Africa }\end{array}$ & 6.6 & 26.4 & 28.5 & 50 & 7.9 & 14.6 & 15.5 & 23 & 1.2 & 13.3 & 13.7 & 27 & 1.4 & 4.5 & 4.6 & 6 \\
\hline $\begin{array}{l}\text { Eastern } \\
\text { Africa }\end{array}$ & 8.1 & 23.8 & 24.4 & 41 & 3.6 & 6.2 & 6.4 & 16 & 2.6 & 13.9 & 14.1 & 22 & 0.9 & 1.8 & 1.8 & 5 \\
\hline $\begin{array}{l}\text { Southern } \\
\text { Africa }\end{array}$ & 0.0 & 12.5 & 16.6 & 43 & 0.1 & 0.3 & 0.7 & 10 & 0.0 & 11.7 & 12.6 & 29 & 0.1 & 0.2 & 0.4 & 2 \\
\hline $\begin{array}{l}\text { OECD } \\
\text { Europe }\end{array}$ & 0.0 & 3.0 & 11.5 & 14 & 0.0 & 5.6 & 12.5 & 14 & 0.0 & 2.7 & 9.1 & 9 & 0.0 & 6.9 & 15.4 & 16 \\
\hline $\begin{array}{l}\text { Eastern } \\
\text { Europe }\end{array}$ & 0.0 & 6.8 & 8.9 & 9 & 0.0 & 6.2 & 6.3 & 8 & 0.0 & 7.9 & 8.0 & 8 & 0.0 & 7.6 & 8.2 & 9 \\
\hline $\begin{array}{l}\text { Former } \\
\text { USSR }\end{array}$ & 0.0 & 78.6 & 84.9 & 127 & 0.8 & 41.9 & 46.6 & 68 & 0.0 & 66.9 & 69.0 & 88 & 0.0 & 60.1 & 61.7 & 78 \\
\hline $\begin{array}{l}\text { Middle } \\
\text { East }\end{array}$ & 0.0 & 0.1 & 3.0 & 13 & 0.0 & 0.0 & 1.3 & 8 & 0.0 & 0.0 & 2.0 & 4 & 0.0 & 0.0 & 1.4 & 3 \\
\hline $\begin{array}{l}\text { South } \\
\text { Asia }\end{array}$ & 0.1 & 12.1 & 15.3 & 27 & 0.6 & 8.2 & 9.8 & 14 & 0.1 & 6.4 & 8.3 & 14 & 0.0 & 1.4 & 2.8 & 6 \\
\hline East Asia & 0.0 & 16.3 & 63.6 & 107 & 0.0 & 0.0 & 5.8 & 23 & 0.0 & 49.8 & 61.1 & 77 & 0.0 & 0.0 & 21.4 & 46 \\
\hline $\begin{array}{l}\text { South- } \\
\text { East Asia }\end{array}$ & 0.0 & 8.8 & 9.7 & 10 & 0.0 & 6.9 & 7.0 & 7 & 0.0 & 2.9 & 3.0 & 3 & 0.0 & 2.5 & 3.5 & 4 \\
\hline Oceania & 0.7 & 33.4 & 35.2 & 55 & 1.6 & 16.6 & 18.0 & 34 & 10.4 & 28.1 & 28.6 & 35 & 5.5 & 24.3 & 24.8 & 30 \\
\hline Japan & 0.0 & 0.0 & 0.1 & 0 & 0.0 & 0.0 & 0.0 & 0 & 0.0 & 0.0 & 0.1 & 0 & 0.0 & 0.0 & 0.2 & 0 \\
\hline Global & 15.5 & 270.6 & 438.5 & 675 & 14.6 & 129.3 & 177.0 & 302 & 14.3 & 271.8 & 344.4 & 443 & 8.0 & 155.3 & 233.8 & 316 \\
\hline
\end{tabular}




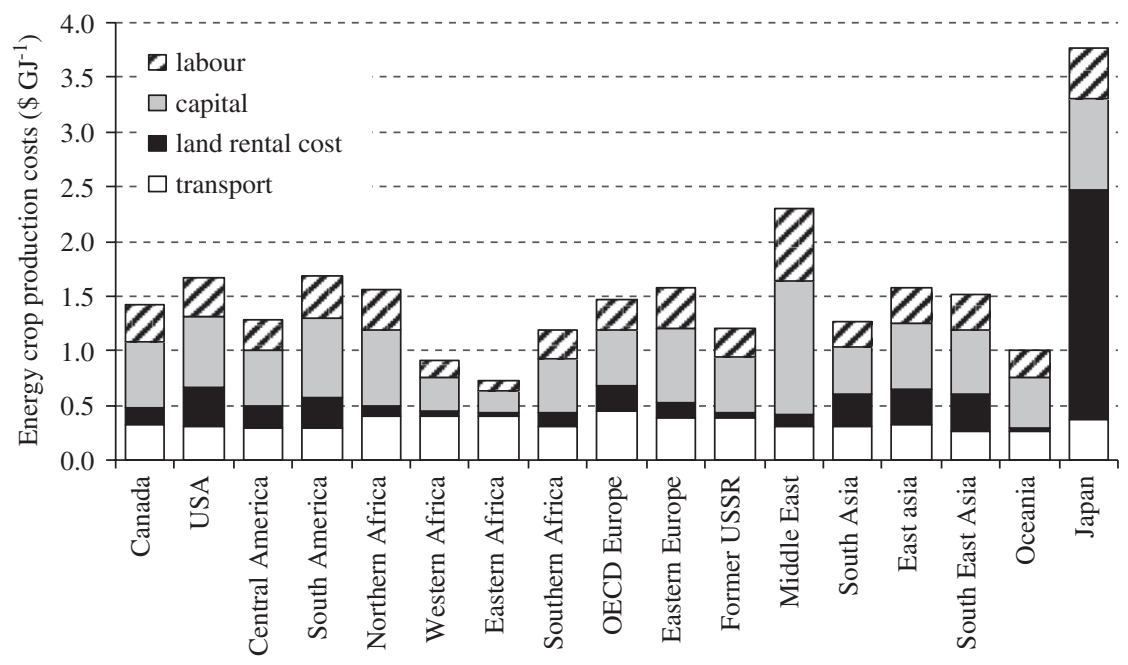

Fig. 8 - Cost breakdown for energy crop production costs in the grid cells with the lowest production costs within each region for the A1 scenario in the year 2050.

Fig. 8 shows for the A1 scenario the lowest regional energy crop production costs and their cost breakdown for the year 2050. The transport cost has a relatively high share in the delivered production costs in some African regions and in Oceania. Except for Japan, land costs do not contribute significantly to the overall production costs of energy crops. The capital and the labour costs are relatively high in the Middle East, due to a low cost reduction factor (Fig. 8).

Fig. 9 shows the map of the world for the A1 scenario for the years 2000 and 2050, indicating where, according to our calculation, energy crops may be produced at costs below or equal to $\$ 2,4$ and $8 \mathrm{GJ}^{-1}$ in the long term. The figure shows that there are large areas in the Former USSR where energy crops may be produced at costs below $\$ 2 \mathrm{GJ}^{-1}$. In Eastern Asia large areas are estimated where energy crops may be produced at costs below $\$ 4 \mathrm{GJ}^{-1}$.

\section{The cost-supply curve of secondary biomass energy}

Fig. 10 shows the global cost-supply curve of biomass liquid fuel in the year 2050 using the primary biomass at abandoned agricultural land and at rest land for the four scenarios. The current retail price of gasoline and diesel is in the order of $\$ 23 \mathrm{GJ}^{-1}$. Assuming crude oil to contribute $60 \%$ to this price, the future costs of FT diesel are in the same order as the current diesel and gasoline costs [66]. As diesel costs fluctuate with the oil prices, the comparison is different for the long term. Studies indicate that the world conventional oil production might peak in the timeframe we consider here, which may increase the diesel price in the long term, see e.g. [67]. The lowest production costs for biomass fuel are found in the A1 and B1 scenarios, at a level of $\$ 9 \mathrm{GJ}^{-1}$. For the A2 and B2 scenario, the lowest costs are found at about $\$ 10 \mathrm{GJ}^{-1}$. The main differences between the two sets of scenarios are caused by the lower geographical potential development over time for A2 and B2, which leads to less technology-induced cost reductions.
The cost-supply curve of biomass electricity is shown in Fig. 11. For comparison, we also indicate the future costs of electricity produced from fossil fuel with carbon capture and storage (CCS) for various fuels and conversion plants, estimated to range from about $\$ 40$ to $100 \mathrm{MWh}$ [68] and present electricity production costs, at an average value for baseload plants of about $\$ 40 \mathrm{MWh}^{-1}$ [65]. These results show that biomass electricity may become able to compete with electricity from fossil fuel-powered plants with CCS. It is found that in largescale biomass fuelled power plants, the present world electricity consumption of $15.7 \mathrm{PWhy}^{-1}$ [70] may be generated in 2050 at costs around $\$ 40 \mathrm{MWh}^{-1}$ in $\mathrm{A} 1$ and $\mathrm{B} 1$ and at costs below $\$ 50 \mathrm{MWh}^{-1}$ for the other scenarios. At costs of $\$ 60$ $\mathrm{MWh}^{-1}$, about 18 (A2) to 53 (A1) $\mathrm{PWh}^{-1}$ can be produced. This is about $0.9-2.6$ times the present electricity production.

\section{Sensitivity analysis}

In this study, the cost distribution of secondary biomass energy within and among regions is only determined by the costs of primary biomass. Therefore we investigate the sensitivity of the production costs of primary biomass for the various input parameters (Fig. 12a and b), restricting ourselves to primary biomass from abandoned agricultural land for the A1 and A2 scenarios. A1 and A2 are chosen as they represent the extreme ranges of the cost-supply curves. For one scenario (A1) we calculate the sensitivity of the cost-supply curve of electricity for the assumptions on conversion technology and costs (Fig. 12c). To this purpose, we have varied the capital-labour substitution coefficient, the management factor (MF), the interest rate, the initial capital and labour inputs, the conversion efficiency, the economic lifetime of the plants and the investment costs within a range of $25 \%$. The progress ratio has been varied between 0.8 and 0.95 (A1) and 0.85 and 0.99 (A2). Fig. 12a-c shows that:

- The production costs of energy crops are most sensitive to the capital-labour substitution. This implies that if 
a
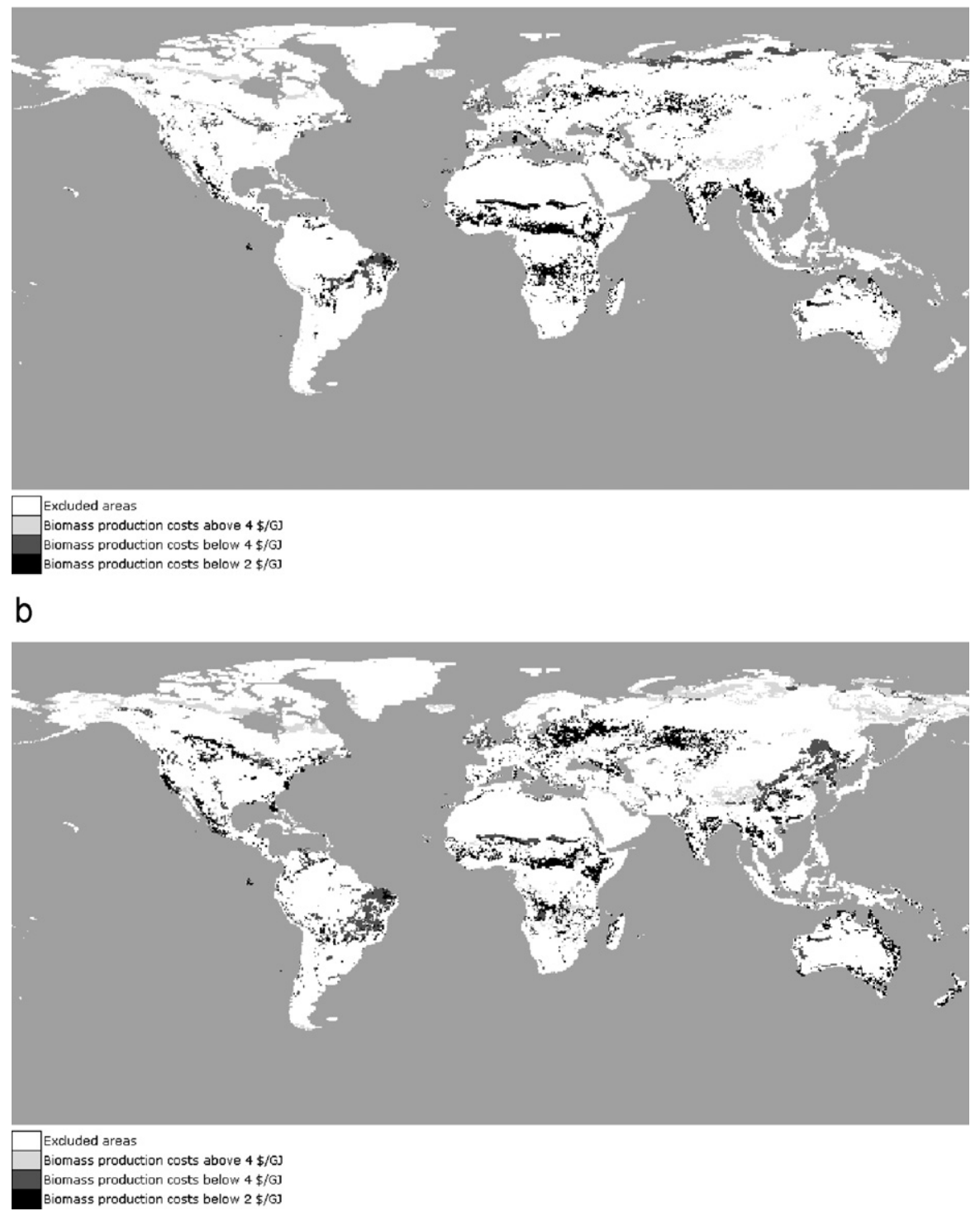

Fig. 9 - (a) Spatial distribution of production cost of energy crops for abandoned and rest land category in the year 2010 for the A1 scenario at abandoned and rest land area. (b) Spatial distribution of production cost of energy crops for abandoned and rest land category in the year 2050 for the A1 scenario at abandoned and rest land area.

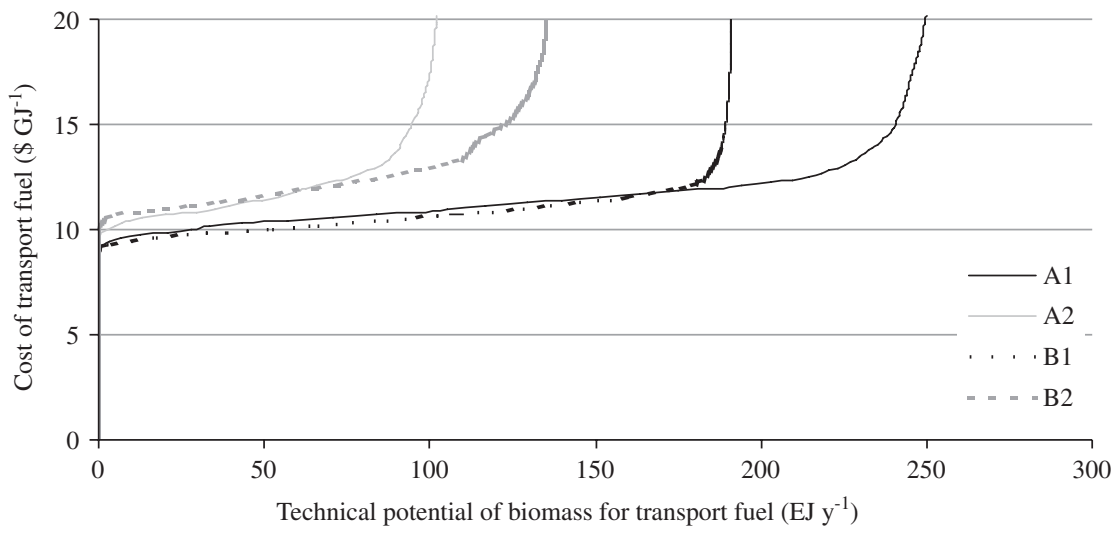

Fig. 10 - The cost supply curve for the year 2050 of biomass liquid fuel (synthetic FT diesel) using energy crop produced at abandoned agricultural land and rest land as feedstock for the four SRES scenarios. 


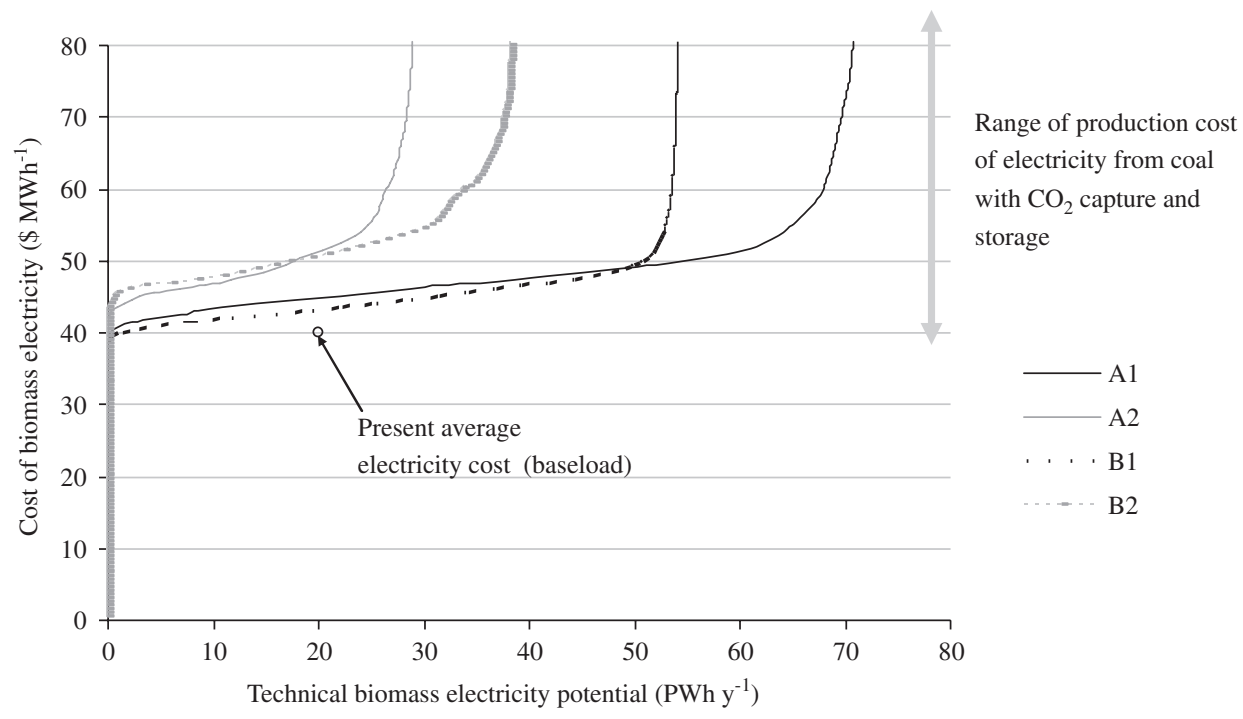

Fig. 11 - The cost-supply curve for the year 2050 of electricity using BIGCC conversion technology using energy crop produced at abandoned agricultural land and rest land as feedstock for the four SRES scenarios compared to present average baseload electricity production costs and estimates of future electricity production cost from coal-fired plants with $\mathrm{CO}_{2}$ capture and storage.
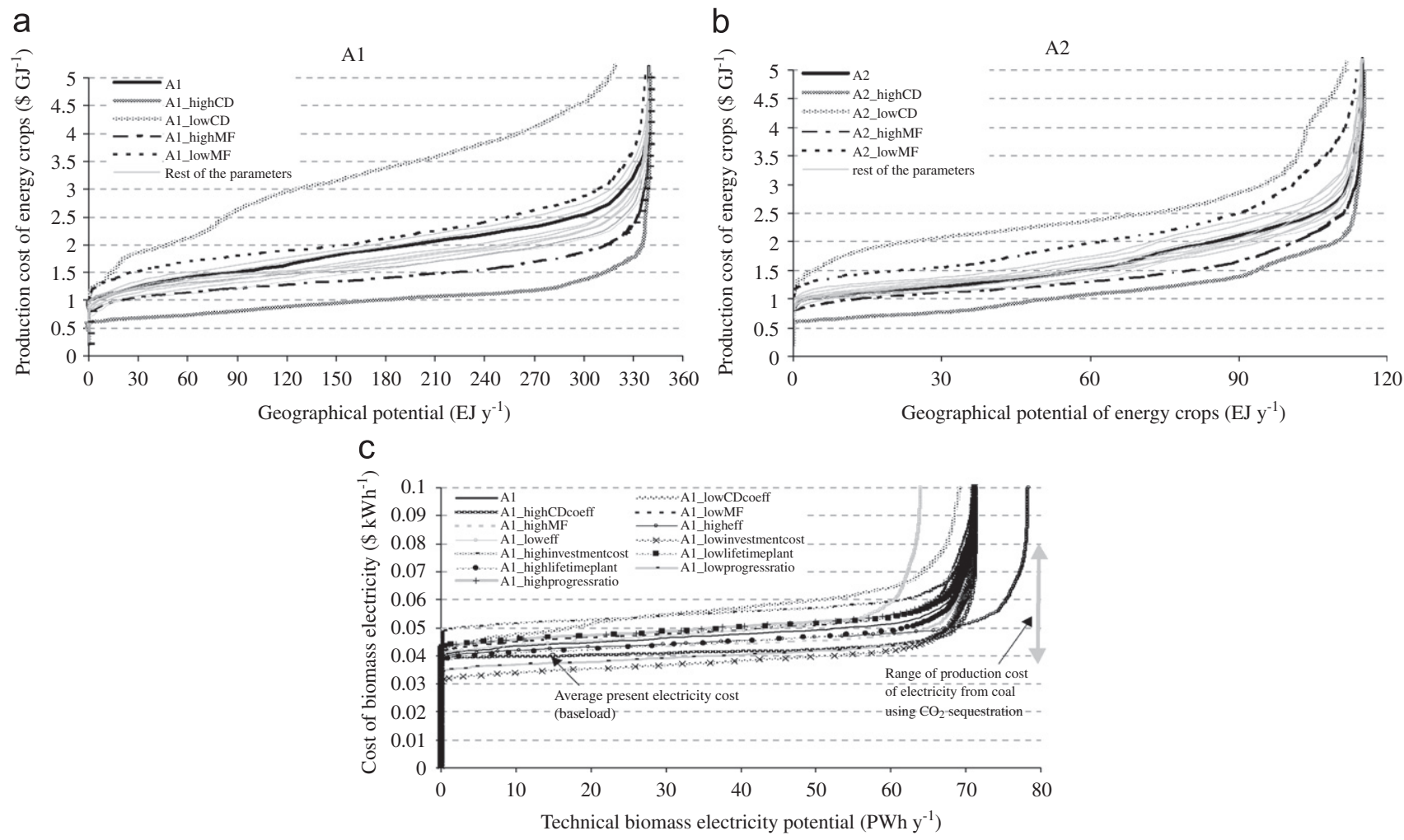

Fig. 12 - (a) Sensitivity analysis of the cost-supply curve of energy crops at abandoned agricultural land for the year 2050 within the A1 scenario by varying most important input parameters by $\pm 25 \%$. The progress ratio has been varied between 0.8 and 0.95 . (b) Sensitivity analysis of the cost-supply curve of energy crops at abandoned agricultural land for the year 2050 within the A2 scenario by varying most important input parameters by $\pm 25 \%$. The progress ratio has been varied between 0.85 and 0.99 . (c) Sensitivity analysis of the cost-supply curve of biomass electricity for the year 2050 for the A1 scenario by varying most important input parameters by $\pm 25 \%$. (CD means substitution elasticity, MF means management factor, eff means conversion efficiency. 
e.g. mechanisation, and so capital-labour substitution stagnates (low $\alpha$ ), the production costs in the year 2050 is almost doubled for the A1 scenario.

- Variation in the land productivity, incorporated by the MF, causes large variations in the production cost of primary biomass. Land productivity increase causes a lower relative land rental cost and an increase of the cost reduction factor due to technological learning.

- The cost-supply curve of energy crops is less sensitive to the other parameters; these are therefore not separately shown in Fig. 12.

- Primary biomass cost in A2 is less sensitive to variations in the input parameters, because the productivity and also labour wages increase over time are less in the A2 scenario compared to A1.

- The variation in the biomass-derived electricity cost varies similar as the production cost of energy crops. However, additional technical parameters are also important, as are the investment costs, resulting in a wide range of biomassderived electricity costs.

Note that in practice not one but all parameters could have a value different from the default numbers used in this study. Consequently, the total variation can be larger than shown here.

\section{Discussion}

Most literature sources on future energy crop costs assume that the capital and labour costs remain constant over time, and the costs reduce only due to autonomous land productivity increase. In our approach, with increasing land productivity, inputs increase proportionally. Nevertheless, our results of the cost estimates for the production of primary and secondary biomass fuels are in line with estimates conducted in other studies, e.g. $[10,25,71,72]$. But, the approach used in this study is still a first exploration and is simplified from reality at various points. This limits the possibility to make firm statements about the future economics of biomass energy in different regions. We would like to point out some remarks for discussion.

Although several studies conclude that if one takes into account the ecological impact and the economics of the production system, woody short-rotation crops are interesting in the long term, see [73]; alternative crops like biomass residue streams or agricultural crops such as sugar beet and perennial grasses can become competitive with short-rotation crops studied here. It is therefore to be noted that biomass liquid fuels and biomass electricity may therefore be available at lower costs than estimated here.

Various cost parameters are included at a global level, e.g. the interest rate, transportation cost and cost inputs of secondary biomass energy are dealt with in a simplified way. Cost estimates in this study show therefore less regional variety than is to be expected in reality. This is also the case for the estimation of the land costs. These are estimated at a regional level, but considerable differences in soil quality and competing options may exist within a region. More importantly, we have not included feedback mechanisms that take into account the impact on land costs from increased competition between food and energy crop supply. This mechanism can affect the land costs as the prices of food crops as well as energy crop increase with an increased demand of biomass for energy, see [74]. For a better understanding of these mechanisms more effort should be put into integrating the food system and the land costs.

Finally, it is to be noted that the assumption on capital-labour substitution implies a reduced socio-economic benefit of employment often mentioned in the context of largescale biomass production. To what extent this is a desirable in terms of sustainable development is not addressed here.

\section{Summary and conclusion}

It can be concluded that large amounts of grown biomass at abandoned agricultural land and rest land, $130-270 \mathrm{EJy}^{-1}$ (about $40-70 \%$ of the present energy consumption) may be produced at costs below $\$ 2 \mathrm{GJ}^{-1}$ by 2050 (present lower limit of cost of coal). Interesting regions because of their low production cost and significant potentials are the Former USSR, Oceania, Eastern and Western Africa and East Asia. Such low costs presume significant land productivity improvements over time and cost reductions due to learning and capital-labour substitution. An assessment of biomass fuel cost, using the primary biomass energy costs, shows that the future costs of biomass liquid fuels may be about twice the present diesel production costs, although this may change in the long term. Biomass-derived electricity costs are at present slightly higher than electricity baseload costs and may directly compete with estimated future production costs of fossil fuel electricity with $\mathrm{CO}_{2}$ sequestration (\$40-100 $\left.\mathrm{MWh}^{-1}\right)$. The present world electricity consumption of around $20 \mathrm{PWhy}^{-1}$ may be generated in 2050 at costs below $\$ 45 \mathrm{MWh}^{-1}$ in $\mathrm{A} 1$ and $\mathrm{B} 1$ and below $\$ 50 \mathrm{MWh}^{-1}$ in $\mathrm{A} 2$ and $\mathrm{B} 2$. At costs of $\$ 60 \mathrm{MWh}^{-1}$, about 18 (A2) to 53 (A1) $\mathrm{PWh} \mathrm{y}^{-1}$ can be produced.

The global curve that consists of all regional curves is found to be relatively flat, but this is highly sensitive to various input parameters, e.g., the elasticity that accounts for the substitution of capital for labour. If mechanisation, and so capitallabour substitution stagnates (low $\alpha$ ), the production costs in the year 2050 is almost doubled for the A1 scenario. To enhance the insight in the future economic potential and competitive position of biomass energy, more research and more input data are required. It is recommended to focus future research on:

- The dynamics of the capital-labour substitution between the two production factors, to understand the impact of rising incomes.

- The technology development of the energy crop productivity for several production systems.

- The impact of large energy crop production on e.g. food production and agricultural land availability.

- The ecological impact of large-scale energy plantations. 
- The possibilities of energy crops under more extensive production systems in comparison with intensive production systems as assumed here.

\section{Acknowledgements}

We are grateful to Richard van den Broek who kindly supplied the background data on the production costs of Nicaragua, Ireland and the Netherlands and to Bas Eickhout for the runs with the IMAGE 2.2 model. Furthermore, we would like to thank Håkan Rosenqvist for data supplied on Swedish costs, Carlo Hamelinck for data supply for the costs of liquid biomass fuels and transport costs and Karst Geurs for information on transport costs. We would furthermore like to thank Tom Kram for valuable comments on the manuscript.

\section{R E F E R E N C E S}

[1] Turkenburg WC. Renewable energy technologies. In: Goldemberg J, editor. World energy assessment. Washington, DC: UNDP; 2000. p. 220-72.

[2] Berndes G, Hoogwijk M, van den Broek R. The contribution of biomass in the future global energy system: a review of 17 studies. Biomass and Bioenergy 2003;25(1):1-28.

[3] Moreira JR, Goldemberg J. The alcohol programme. Energy Policy 1999;27:229-45.

[4] Shapouri H, Gallagher P, Graboski M. The USDA 1998 US ethanol cost of production survey. Washington, DC: USAD, Office of Energy Policy and New Uses, Iowa State University, Colorado School of Mines; 1998.

[5] AEA Technology. Comparison of public acceptability of energy from waste and energy from biomass residues in 5 EU states. Oxfordshire, 2001. p. 210.

[6] van den Broek R. Sustainability of biomass electricity systems - an assessment of costs, macro-economic and environmental impacts in Nicaragua, Ireland and the Netherlands. Utrecht: Utrecht University; 2000. p. 215.

[7] Hall DO, Rosillo-Calle F, Williams RH, Woods J. Biomass for energy: supply prospects. In: Kelly JTBH, Reddy AKN, Williams RH, editors. Renewable energy-sources for fuels and electricity. Washington, DC: Island Press; 1993. p. 1160.

[8] van den Broek R, Teeuwisse S, Healion K, Kent T, van Wijk A, Faaij A, et al. Potentials for electricity production from wood in Ireland. Energy 2001;26:991-1013.

[9] Hoogwijk M, Faaij A, Eickhout B, de Vries B, Turkenburg W. Global potential of biomass for energy out to 2100 , for four IPCC SRES land-use scenarios. Biomass and Bioenergy 2005;29:225-57.

[10] Junginger M, Faaij A, van den Broek R, Koopmans A, Hulscher W. Electricity generation from agricultural and forest residues in Northeastern Thailand. Biomass and Bioenergy 2001;21(4):259-75.

[11] Graham R, Lichtenberg LE, Roningen VO, Shapouri H, Walsh $\mathrm{ME}$. The economics of biomass production in the United States. In: Second biomass conference of the Americas: energy, environment, agriculture, and industry. Portland, OR: NREL; 1995.

[12] Walsh ME. Method to estimate bioenergy crop feedstock supply curves. Biomass and Bioenergy 2000;18:283-9.

[13] Roos A, Rakos C. The limits of modelling. Experiments with bioenergy in practise-could models have predicted this outcome? Biomass and Bioenery 2000;18:331-40.
[14] IMAGEteam H. The IMAGE 2.2 implementation of the SRES scenarios: a comprehensive analysis of emissions, climate change and impacts in the 21st century. Bilthoven: National Institute for Public Health and the Environment (CDRom); 2001.

[15] Rosenqvist H. Personal communication on energy crop production cost in Sweden. Luleå: University of Technology; 2002.

[16] Sudha P, Somashekhar HI, Rao S, Ravindranath NH. Sustainable biomass production for energy in India. Biomass and Bioenergy 2003;25(5):501-15.

[17] Larson ED, Williams RH. Biomass plantation energy systems and sustainable development. In: Goldemberg J, Johansson $\mathrm{TB}$, editors. Energy as an instrument for socio-economic development. New York: United Nations Development Programme; 1995 p. 16.

[18] Nakicenovic N, Swart R, Metz B, et al. Special report on emission scenarios. Cambridge: Cambridge University Press; 2000.

[19] Coelman BT. Mogelijkheden voor Kleinschalige Energieopwekking met Geteelde Biomassa. Wageningen: CPV, IMAG-DLO, ECN; 1996.

[20] Perlack RD, Wrights L. Technical and economic status of wood energy feedstock production. Energy 1995;20(4):279-84.

[21] Perlack RD, Wright L, Huston MA, Schramm WE. Biomass fuel from woody crops for electric power generation. Washington, DC: ORNL; 1995.

[22] Perlack RD. Determination of the potential market size and opportunities for biomass-to-electricity projects in China. Tennessee: Oak Ridge National Laboratory; 1995. p. 5.

[23] Hillring B. Price formation on the Swedish woodfuel market. Biomass and Bioenergy 1999;17:445-54.

[24] Venendaal R, Jorgensen U, Fosters CA. European energy crops: a synthesis. Biomass and Bioenergy 1997;13(3):147-85.

[25] Biewinga EE, van den Bijl G. Sustainability of energy crops in Europe; a methodology developed and applied. Utrecht: CLM; 1996. p. 209.

[26] de Jager D, Faaij APC, Troelstra WP. Kosten-effectiviteit van transportbrandstoffen uit biomassa. Utrecht: NOVEM; 1998. p. 82.

[27] Williams RH, Larson ED. Advanced gasification-based biomass power generation. In: Johansson TB, Kelly H, Reddy AKN, Williams RH, editors. Renewable energy-sources for fuels and electricity. Washington, DC: Island Press; 1993.

[28] Phillips VD, Liu W, Merriam RA, Bain L. Short-rotation forestry as alternative land use in Hawaii. Biomass and Bioenergy 1995;8(4):235-44.

[29] Marrison CI, Larson ED. Cost versus scale for advanced plantation-based biomass energy systems in the USA and Brazil. In: Second biomass conference of the Americas, Portland, OR, 1995.

[30] Azar C, Larson ED. Bioenergy and land-use competition in northeast Brazil. Energy for Sustainable Development 2000;4(3):51-8.

[31] Faundez P. Potential cost of four short-rotation silvicultural regimes used for the production of energy. Biomass and Bioenergy 2003;24(4-5):373-80.

[32] Varian HR. Intermediate microeconomics-a modern approach. W.W. Norton \& Company: New York; 1996. p. 650.

[33] Dalton TJ, Master WA, Foster KA. Production cost and input substitution in Zimbabwe's smallholder agriculture. Agricultural Economics 1997;17:201-9.

[34] Van Zyl J, Vink N, Fenyes T. Labour-related structural trends in South African maize production. Agricultural Economics 1987;1:241-58.

[35] Sharma SC. Technological change and elasticities of substitution in Korean agriculture. Journal of Development Economics 1991;35:147-72. 
[36] van den Broek R, van Wijk A, Turkenburg W. Electricity from energy crops in different settings-a country comparison between Nicaragua, Ireland and the Netherlands. Biomass and Bioenergy 2002;22(2):79-98.

[37] McDonald A, Schrattenholzer L. Learning curves and technology assessment. International Journal of Technology Management 2002;23(7/8):718-45.

[38] Faaij A, Meuleman B, Waldheim L, Olsson E, Oudhuis A, van Wijk A, et al. Long term perspectives of biomass integrated gasification/combined cycle (BIG/CC) technology: costs and efficiency and a comparison with combustion. Utrecht: Department of Science, Technology and Society, Utrecht University; 1998. p. 93

[39] Tijmensen MJA, Faaij APC, Hamelinck C, Hardeveld M. Exploration of the possibilities for production of Fischer Tropsch liquids and power via biomass gasification. Biomass and Bioenergy 2002;23(2):129-52.

[40] Larson ED, Jin H. Biomass conversion to Fischer-Tropsch liquids: preliminary energy balances. In: Fourth biomass conference of the Americas. Oakland, Oxford: Elsevier Science Ltd.; 1999.

[41] Chum HL, Overend RP. Biomass and renewable fuels. Fuel processing technology 2001;71:187-95.

[42] Hamelinck C, Faaij A, den Uil H, Boerrigter H. Production of FT transportation fuels from biomass; technical options, process analysis and optimisation and development potential. Energy, the International Journal 2003.

[43] Dornburg V. A system analysis of biomass energy systems in relation to scale. Utrecht: Department of Science, Technology and Society; 1999.

[44] Dornburg V, Faaij A. Efficiency and economy of wood-fires biomass energy systems in relation to scale regarding heat and power generation using combustion and gasification technologies. Biomass and Bioenergy 2001;21:91-108.

[45] Kunte A, Hamilton K, Dixon J, Clemens M. Estimating national wealth: methodology and results. Indicators and environmental valuation. Washington, DC: The World Bank; 1998. p. 44.

[46] Graveland C, Bouwman AF, de Vries B, Eickhout B, Strengers $B$. Projections of multi-gas emissions and carbon sinks, and marginal abatement cost functions modeling for land-sea related sources. Bilthoven: RIVM; 2002. p. 92.

[47] FAO. Statistics on prices paid by farmers for means of production. Rome: Food and Agricultural Organization; 1997.

[48] Turhollow A. Cost of producing biomass from riparian buffer strips. Oakridge, TN: ORNL; 2000.

[49] Toivonen RM, Tahvanainen LJ. Profitability of willow cultivation for energy production in Finland. Biomass and Bioenergy 1998;15(1):27-37.

[50] Rosenqvist H, Roos A, Ling E, Hektor B. Growers in Sweden. Biomass and Bioenergy 2000;18(2):137-45.

[51] van den Broek R, Faaij A, van Wijk A, Kent T, Bulfin M, Healion $\mathrm{K}$, et al. Willow firing retrofitted Irish peat power plants. Biomass and Bioenergy 1997;12(2):75-90.

[52] Dornburg V, Termeer G, Faaij A. Economic and greenhouse gas emission analysis of bio-energy production using multiproduct crops-case studies for the Netherlands and Poland. Biomass and Bioenergy 2005;28(5):454-74.

[53] De la Torre Ugarte DG, Walsh ME, Shapouri H, Slinsky SP. The economic impacts of bioenergy crop production on US agriculture. Tennessee: APAC, DOE-ORNL; 2000. p. 40.

[54] van den Broek R, van Wijk A, Turkenburg W. Farm-based versus industrial eucalyptus plantations for electricity generation in Nicaragua. Biomass and Bioenergy 2000;19(5):295-310.

[55] Heilman P, Norby RJ. Nutrient cycling and fertility management in temperate short rotation forest systems. Biomass and Bioenergy 1998;14(4):361-70.

[56] Turhollow A. The economics of energy crop production. Biomass and Bioenergy 1994;6(3):229-41.

[57] Lewandowski I. Energiepflanzenproduktion, Energie aus Biomass-Grundlagen. In: Kaltschmitt M, Hartmann H, editors. Techniken und Verfahren. Berlin: Springer; 2001. p. 57-93.

[58] Tuskan GA. Short-rotation woody crop supply systems in the United States: what do we know and what do we need to know? Biomass and Bioenergy 1998;14(4):307-15.

[59] Strauss CH, Wright LL. Woody biomass production costs in the United States: an economic summary of commercial populus plantations systems. Solar Energy 1990;45(2):105-10.

[60] Hamelinck C, Suurs RAA, Faaij A. International bioenergy transport costs and energy balances. Utrecht: Utrecht University, Copernicus Institute; 2003. p. 53.

[61] Ericson K, Nillson LJ. International biofuel trade-a study of the Swedish import. Biomass and Bioenergy 2003;26(3):205-20.

[62] Davis SC. Transportation energy book. Oakridge, TN: DOE; 2001. p. 197.

[63] Heller M, Keoleian GA, Volk TA. Life cycle assessment of a willow bioenergy cropping system. Biomass and Bioenergy 2003;25(2):147-65.

[64] Agterberg A, Faaij A. Bio-energy trade: possibilities and constraints on short and longer term. Utrecht: Utrecht University; 1998.

[65] OECD/IEA. Key world energy statistics. Paris: IEA; 2003.

[66] Goldemberg J. World energy assessment. New York: United Nations Development Programme, United Nations Department of Economic and Social Affairs: World Energy Council; 2000. p. 508.

[67] EIA, Gasoline and fuel update, US gasoline and diesel fuel updates, available at $\langle w w w . e i a . d o e . g o v\rangle$. Accessed December 2007.

[68] Hakes J. Long term world oil supply. Washington, DC: EIA; 2000. p. 27.

[69] IPCC. IPCC special report on carbon dioxide capture and storage. In: Metz B, Davidson O, de Coninck HC, Loos M, Meyer LA, editors. Prepared by working group III of the Intergovernmental Panel on Climate Change. Cambridge, UK and New York, NY, USA: Cambridge University Press; 2005. 442pp.

[70] BP. BP statistical review of world energy, available at $\langle$ www.bp.com〉. 2002.

[71] Hughes EE, Wiltsee GA. Comparative evaluation of fuel costs from energy crops. In: Second biomass conference of the Americas: energy, environment, agriculture and industry. Portland, OR: NREL; 1995.

[72] Walsh M, Graham R. Biomass feedstock supply analysis: production costs, land availability, yields. Oakridge, TN: ORNL; 1995.

[73] Kaltschmitt M, Reinhardt GA, Stelzer T. Life cycle analysis of biofuels under different environmental aspects. Biomass and Bioenergy 1997;12(2):121-34.

[74] Azar C, Berndes G. The implication of carbon dioxide abatement policies on food prices. In: Dragun AK, Tisdell C, editors. Sustainable agriculture and environment globalisation and the impact of trade and liberalisation. Edward Edgar Publisher; 1999. p. 153-68. 